Article

\title{
Cymbopogon winterianus Essential Oil Attenuates Bleomycin-Induced Pulmonary Fibrosis in a Murine Model
}

\author{
Lívia A. Tavares ${ }^{1}{ }^{(}$, Allan A. Rezende ${ }^{1}{ }^{\oplus}$, Jymmys L. Santos ${ }^{2}$, Charles S. Estevam ${ }^{2}$, Ana M. O. Silva ${ }^{3}$, \\ Jaderson K. Schneider ${ }^{4}$, John L. S. Cunha ${ }^{5}$, Daniela Droppa-Almeida ${ }^{6}$, Ivan J. Correia-Neto ${ }^{7}$, \\ Juliana C. Cardoso ${ }^{1,6}\left(\mathbb{0}\right.$, Patricia Severino ${ }^{1,6,8} \mathbb{C}$, Eliana B. Souto ${ }^{8,9, *}$ and Ricardo L. C. de Albuquerque-Júnior ${ }^{1,6, *}$
}

1 Post-Graduating Program in Biotechnology, Brazilian Biotechnology Northeast Network, Tiradentes University, Aracaju 49010-390, Brazil; livianjos15@hotmail.com (L.A.T.); allan_a.rezende@hotmail.com (A.A.R.); juaracaju@yahoo.com.br (J.C.C.); pattypharma@gmail.com (P.S.)

2 Post-Graduating Program in Biotechnology, Brazilian Biotechnology Northeast Network, Federal University of Sergipe, São Cristóvão 49100-000, Brazil; jymmyslopes@yahoo.com.br (J.L.S.); cse.ufs@gmail.com (C.S.E.)

3 Department of Nutrition, Federal University of Sergipe, São Cristóvão 49100-000, Brazil; anamaraufs@gmail.com

4 Post-Graduating Program in Industrial Biotechnology, Tiradentes University, Aracaju 49010-390, Brazil; jadersonqmc@gmail.com

check for
updates

Citation: Tavares, L.A.; Rezende, A.A.; Santos, J.L.; Estevam, C.S.; Silva, A.M.O.; Schneider, J.K.; Cunha, J.L.S.; Droppa-Almeida, D.; Correia-Neto, I.J.; Cardoso, J.C.; et al. Cymbopogon winterianus Essential Oil Attenuates Bleomycin-Induced Pulmonary Fibrosis in a Murine Model. Pharmaceutics 2021, 13, 679. https: / / doi.org/10.3390/ pharmaceutics13050679

Academic Editors: Javier Garcia-Pardo, Maria Camilla Bergonzi and Charles M. Heard

Received: 6 April 2021 Accepted: 3 May 2021 Published: 9 May 2021

Publisher's Note: MDPI stays neutral with regard to jurisdictional claims in published maps and institutional affiliations.

Copyright: (c) 2021 by the authors. Licensee MDPI, Basel, Switzerland. This article is an open access article distributed under the terms and conditions of the Creative Commons Attribution (CC BY) license (https:// creativecommons.org/licenses/by/ $4.0 /)$.
5 Post-Graduating Program in Stomatopathology, University of Campinas, Campinas 13083-970, Brazil; lennonrrr@gmail.com

6 Post-Graduating Program in Health and Environment, Tiradentes University, Aracaju 49032-490, Brazil; danieladroppa@gmail.com

7 Post-Graduating Program in Dental Science, University of São Paulo, São Paulo 05508-010, Brazil; ivanc.neto@gmail.com

8 Faculty of Pharmacy, University of Coimbra, Pólo das Ciências da Saúde, Azinhaga de Santa Comba, 3000-548 Coimbra, Portugal

9 CEB-Centre of Biological Engineering, University of Minho, Campus de Gualtar, 4710-057 Braga, Portugal

* Correspondence: ebsouto@ff.uc.pt (E.B.S.); ricardo_albuquerque@unit.br (R.L.C.d.A.-J.)

Abstract: The essential oil of Cymbopogon winterianus (EOCW) is a natural product with antioxidant, anti-inflammatory, and antifibrotic properties. We studied the effect of EOCW in the progression of histological changes of pulmonary fibrosis (PF) in a rodent model. The oil was obtained by hydrodistillation and characterized using gas chromatography-mass spectrometry. Intratracheal instillation of bleomycin was performed in 30 rats to induce PF, while Sham animals were subjected to instillation of saline solution. The treatment was performed using daily oral administration of distilled water, EOCW at 50, 100, and $200 \mathrm{mg} / \mathrm{kg}$, and deflazacort (DFC). After 28 days, hemogram and bronchoalveolar lavage fluid (BALF), tissue levels of malondialdehyde (MDA), superoxide dismutase (SOD), and catalase (CAT) were assayed. Histological grading of PF, immunohistochemical expression of $\alpha$-smooth muscle actin ( $\alpha$-SMA), and transforming growth factor- $\beta$ (TGF- $\beta$ ) were also analyzed. The EOCW major compounds were found to be citronellal, geraniol, and citronellol. EOCW significantly reduced inflammation in BALF, reduced MDA levels, and increased SOD activity. EOCW attenuated histological grading of PF and reduced immunohistochemical expression of $\alpha$-SMA and TGF- $\beta$ in a dose-dependent way, likely due to the reduction of oxidative stress, inflammation, and TGF- $\beta$-induced myofibroblast differentiation.

Keywords: pulmonary fibrosis; terpenes; Wistar rats; myofibroblasts; histological labelling; immunohistochemistry

\section{Introduction}

Idiopathic pulmonary fibrosis (PF) is a chronic interstitial lung disease that affects over 3 million individuals worldwide, with a mean survival time of about 3 years, characterized by progressive deposition of fibrotic tissue in the lungs and overall poor prognosis $[1,2]$. 
Studies have suggested that the incidence and prevalence of idiopathic PF is continuously growing, and that PF is strongly associated with advanced age [3,4].

The main pathologic changes that play a critical role in the pathogenesis of idiopathic $\mathrm{PF}$ are oxidative stress, inflammation, and collagen deposition, but the comprehensive understanding of the pathobiology of the disease remains elusive [5]. However, microinjury of the alveolar epithelium induced by environmental and microbial exposures (metal and wood dust, viruses, and drugs) and individual genetic factors (dysfunctions of the MUC5B gene, causing reduction of mucociliary clearance enhancing lung injury) have been recognized as the first drivers of idiopathic PF [2,6]. Subsequently, fibroblast and myofibroblasts collections that actively produce extracellular matrix, including high levels of collagen, are hallmarks of idiopathic PF progression. The source of these cells has been related to epithelial-mesenchymal transition (EMT), a pathophysiological process that is defined by the detection of several biomarkers that mirror the loss of epithelial phenotype and the gain of mesenchymal one, such as cytoskeletal proteins involved in cell contraction (e.g., $\alpha$-smooth muscle actin) [7]. EMT events are involved in the direct conversion of damaged lung epithelial cells into mesenchymal fibroblasts, and the persistence of EMT-inducing signals seems to promote extracellular matrix accumulation causing tissue scarring in idiopathic $\mathrm{PF}[8,9]$.

Transforming growth factor beta (TGF- $\beta$ ) is a cytokine that plays a key role in the pathogenesis of idiopathic PF [10]. Increased expression of TGF- $\beta$ has been demonstrated to precede collagen synthesis and deposition in animal models of lung fibrosis [11], and adenoviral-mediated gene transfer of active TGF- $\beta$ has induced severe fibrosis in rodent lungs [12]. TGF- $\beta$ modulates EMT-related transdifferentiation of pulmonary fibroblasts and type I alveolar cells into myofibroblasts, such as plasma membrane junctional and adhesion complexes adaptation, and cytoskeleton reorganization [13]. An increased number of myofibroblasts, identified by their expression of $\alpha$-smooth muscle actin ( $\alpha$-SMA), has been related to the progression of pulmonary fibrosis [14].

The multifactorial etiopathogenetic factors involving continuous oxidative stress, unresolved inflammation, and tissue scarring have made the management of the idiopathic PF so challenging that few therapeutics have succeeded in the clinic, and they have failed to improve patient survival [15]. As most therapeutic agents (corticosteroids, antifibrotic, and immunosuppressant drugs) have focused on one step at a time of idiopathic PF pathogenesis, the results tend to be unpromising [16,17]. Thus, therapeutic approaches based on traditional knowledge, such as plant-derived compounds, able to act in different steps of idiopathic PF pathogenesis, might be a successful strategy to treat the disease [18].

Cymbopogon winterianus Jowitt is an aromatic grass cultivated in India and Brazil. The essential oil obtained from its leaves has demonstrated anti-inflammatory and antioxidant properties [19] and low toxicity [20]. These biological properties are potentially attributed to its the major monoterpenes, namely, geraniol (40.06\%), citronellal (27.44\%), and citronellol $(10.45 \%)$ [21]. In fact, geraniol reduces pro-oxidative lipid peroxidation and nitric oxide (NO) and reactive oxygen species (ROS) production [22], whereas citronellal inhibits proinflammatory 5-lipoxygenase (5-LOX) synthesis [23]. Citronellol inhibits inducible nitric oxide synthase (iNOS) and cyclooxygenase-2 (COX-2) expression, resulting in antioxidant and anti-inflammatory effects [24].

There is also evidence that the EOCW chemical constituents modulate the fibrosis process in different tissues. Geraniol attenuates fibrosis, prevents atherogenesis, and exerts anti-inflammatory effects by the NF- $\mathrm{kB}$ signaling pathway on atherogenic diet induced fibrosis in hamsters [25]. Furthermore, the essential oil of Cichorium glandulosum Boiss et Huet, whose major chemical constituent is citronellol (74.060\%), reduces the extracellular fibrillar proteins deposition, such as collagen and elastic fibers, on carbon tetrachlorideinduced liver fibrosis in rats [26].

Considering the antioxidant, anti-inflammatory, and antifibrotic properties of the essential oil of Cymbopogon winterianus, and its chemical composition, we hypothesize that 
it may prevent or attenuate the progression of histological changes of pulmonary fibrosis in a bleomycin-induced murine model.

\section{Materials and Methods}

\subsection{Sampling Site and Plant Material}

Fresh leaves of Cymbopogon Winterianus were obtained from the Brazilian Agricultural Research Corporation (EMBRAPA), who collected the samples in July of 2018 in Aracaju (coordinates: $10^{\circ} 57^{\prime} 02.4^{\prime \prime} \mathrm{S} 37^{\circ} 03^{\prime} 07.4^{\prime \prime} \mathrm{W}$ ), Sergipe, Brazil. The specimens were deposited in the herbarium of the Department of Botany nf the Tiradentes University with the registration no. 0844 .

\subsection{Extraction and Analysis of the Essential Oil}

The fresh leaves of Cymbopogon Winterianus were dried at $60 \pm 1^{\circ} \mathrm{C}$ for four days in a drying oven (MA035/5, Marconi ${ }^{\circledR}$, Piracicaba, São Paulo,, Brazil). Hydrodistillation was used to obtain the essential oil of the leaves in a Clevenger-type apparatus. The obtained essential oil was separated from the aqueous phase and stored in an amber bottle in a freezer (at $-4{ }^{\circ} \mathrm{C}$ ) until further used. The chemical analysis of its components was performed by a GC/MS (GCMSQP2010 Ultra, Shimadzu Corporation, Kyoto, Japan) equipped with an AOC-20i autoinjector (Shimadzu Corporation, Kyoto, Japan), following a previously described method [27], with some modifications. The separations were performed on $30 \mathrm{~m}$, Rtx ${ }^{\circledR}-5$ MS Restek fused silica capillary column (5\% diphenyl-95\% dimethylpolysiloxane) with a $0.25 \mathrm{~mm}$ internal diameter and $0.25 \mathrm{~mm}$ film thickness. Helium 5.0 was used as the carrier gas at a flow rate of $1.0 \mathrm{~mL} / \mathrm{min}$. The injection temperature was $280{ }^{\circ} \mathrm{C}$. The volume of $1.0 \mu \mathrm{L}(10 \mathrm{mg} / \mathrm{mL})$ of sample was injected at a split ratio of 1:30. The oven temperature was programmed isothermally at $50{ }^{\circ} \mathrm{C}$ for $1.5 \mathrm{~min}$, followed by a rate increase of $4{ }^{\circ} \mathrm{C} / \mathrm{min}$ until reaching $200{ }^{\circ} \mathrm{C}$, and then at $10^{\circ} \mathrm{C} / \mathrm{min}$ up to $300^{\circ} \mathrm{C}$, which was kept for $5 \mathrm{~min}$. For the GC/MS, the ionic capture detector impact energy was $70 \mathrm{eV}$. The fragments were analyzed by a quadrupolar system programmed to filter fragments/ions with $\mathrm{m} / \mathrm{z}$ from 40 to $500 \mathrm{Da}$ and detected by an electron multiplier. The data were processed with the aid of GCMS Postrun Analysis software (Labsolutions, Shimadzu Corporation, Kyoto, Japan). The components were identified by a comparison of their retention times with those available in the literature [28]. The retention index was determined using the Van den Dool and Kratz (1963) equation [29], for a homologous series of n-alkanes (nC9-nC18). The components of the essential oil were also identified by comparing their mass spectra with the spectra available in the WILEY8, NIST107, and NIST21 equipment databases, which allow the comparison of mass spectral data sets and the use of a minimum similarity index of $80 \%$.

\subsection{Experimental Procedures of Lung Fibrosis: Induction and Treatment}

The animal experiments were approved by the Ethics Committee on Animal Research of the Tiradentes University (CEUA/UNIT) through Opinion No. \#020917. Ethics principles Use of Laboratory Animals of the Brazilian Society of Laboratory Animal Science (SBCAL/COBEA) were followed together with the 3R principles of the EU Directive 2010/63/EU transferred to the national Decreto-Lei 113/2013 (in Portugal), the 2001/83/EC and $86 / 609 / \mathrm{EEC}$ (on the protection of animals used for experimental and other scientific), and the Amsterdam protocol on animal protection and welfare of 1997 FP7 Decision number 1982/2006EC. Thirty-six adult male Wistar rats (Rattus norvegicus albinus) weighing $225 \pm 25$ g were randomly assigned into six experimental groups (Table 1). Animals were housed in plastic cages with bedding of wood shavings, which was replaced daily, under controlled temperature at $22{ }^{\circ} \mathrm{C}$ and a $12 \mathrm{~h}$ light/dark regimen, with water and food ad libitum (Labina ${ }^{\circledR}$; Purina, São Paulo, Brazil). Bleomycin-induced lung fibrosis was performed according to Bahri et al. (2017) [5]. The animals were subjected to dissociative anesthesia with intraperitoneal administration of $0.10 \mathrm{~mL} / 100 \mathrm{~g}$ of $10 \%$ ketamine (Ketamine $^{\circledR}$, Rhobifarma Indústria Farmacêutica Ltda, Hortolândia, São Paulo, Brazil) 
and $0.25 \mathrm{~mL} / 100 \mathrm{mg}$ of xylazine (Anasedan ${ }^{\circledR}$ - Sespo Ind e Com. Ltda, Paulínia, São Paulo, Brazil, ). Briefly, induction of fibrosis was carried out by intratracheal instillation of $5.0 \mathrm{mg} / \mathrm{kg}$ body weight (bw) of bleomycin sulfate (Cinaleo ${ }^{\circledR}$, Laboratories Meizler, São Paulo, Brazil) dissolved in $0.5 \mathrm{~mL}$ of sterile saline. The same procedures were performed in the control group (Sham), using saline solution instead of bleomycin. The treatment of the animals proposed for the different experimental groups started three days after these procedures. Deflazacort (Calcort ${ }^{\circledR}$, Merrell Lepetit, São Paulo, Brasil), soybean oil, and EOCW were administered daily by gavage, for 28 days. The animals were euthanized by cardiac puncture exsanguination, and the lungs were surgically removed. The left lung was fixed in $10 \%$ phosphate-buffered formalin ( $\mathrm{pH} 7.4$ ) for further histological procedures. The right accessory pulmonary lobes were frozen $\left(-80^{\circ} \mathrm{C}\right)$ for further colorimetric assays.

Table 1. Distribution of animals in experimental groups according to treatment.

\begin{tabular}{lll}
\hline Groups $(\boldsymbol{n}=\mathbf{6})$ & Pulmonary Damage Procedure & Oral Administration (Treatment) $^{\text {a }}$ \\
\hline Sham $^{\mathrm{b}}$ & Saline solution & Soybean oil \\
Vehicle $^{\mathrm{c}}$ & Bleomycin sulfate $(5 \mathrm{mg} / \mathrm{kg})$ & Soybean oil \\
EOCW $50^{\mathrm{c}}$ & Bleomycin sulfate $(5 \mathrm{mg} / \mathrm{kg})$ & $50 \mathrm{mg} / \mathrm{kg}$ essential oil of Cymbopogon winterianus \\
EOCW $100^{\mathrm{c}}$ & Bleomycin sulfate $(5 \mathrm{mg} / \mathrm{kg})$ & $100 \mathrm{mg} / \mathrm{kg}$ essential oil of Cymbopogon winterianus \\
EOCW $200^{c}$ & Bleomycin sulfate $(5 \mathrm{mg} / \mathrm{kg})$ & $200 \mathrm{mg} / \mathrm{kg}$ essential oil of Cymbopogon winterianus \\
DFC ${ }^{c}$ & Bleomycin sulfate $(5 \mathrm{mg} / \mathrm{kg})$ & $1.0 \mathrm{mg} / \mathrm{kg}$ Deflazacort \\
\hline
\end{tabular}

${ }^{\mathrm{a}}$ The volume administered was $0.2 \mathrm{~mL}$, regardless of the treatment. ${ }^{\mathrm{b}}$ Intratracheal instillation of saline and ${ }^{\mathrm{c}}$ bleomycin to induce pulmonary fibrosis.

\subsection{Assessment of the Body Weight of the Animals}

The body weight of the animals was assessed at the beginning and at the end of the experiment. The percentage of body weight gain in each group was calculated using the Equation (1).

$$
B W g=\frac{f B w-i B w}{f B w} \times 100
$$

where $B W g$ is the percentage of body weight gain, $f B W$ is the body weight at the end of the experimental time, and $i B W$ is the body weight at the beginning of the experimental time.

\subsection{Hematological Analysis of the Peripheral Blood}

Hematologic analysis was performed using the automatic hematologic analyzer Sysmex Xs1000i (Sysmex America, Inc., Mundelein, IL, USA). Differential leukocyte counting was performed with an optical microscopy after staining with Pappenheim's method for each case. Data were expressed as absolute number of cells per $\mathrm{mm}^{3}$ of peripheral blood.

\subsection{Analysis of the Bronchoalveolar Lavage Fluid (BALF)}

After cardiac puncture exsanguination, $1 \mathrm{~mL}$ of sodium phosphate buffer was slowly injected into the lungs through a catheter and then immediately aspirated. Samples were centrifuged, supernatant was stored at $-80^{\circ} \mathrm{C}$, and the pellet was resuspended in $250 \mu \mathrm{L}$ of sodium phosphate buffer. The total number of cells was assessed by direct counting in a hemocytometer using the Trypan blue exclusion method. For cell differentiation analysis, $200 \mu \mathrm{L}$ of cell suspension was added in a cytospin slide chamber (Shandon EZ Double Cytofunnel, Thermo Scientific, Waltham, MA, USA), spun at 800 rpm for 5 min in a Cytospin 4 (Thermo Scientific, USA) and stained with Stain Set Diff-Quik (Siemens Healthcare Diagnosis Inc., Newark, NJ, USA). Percentages of macrophages, neutrophils, and lymphocytes were obtained and adjusted by total cell number.

\subsection{Assessment of Lipid Peroxidation and Mda Tissue Levels}

Lipid peroxidation was determined based on the detection of thiobarbituric acid (TBA) reactive products [17]. A reaction with TBA can detect small amounts of lipid peroxides, 
and more particularly, the free malondialdehyde (MDA) produced during the oxidative breakdown of lipids and polyunsaturated fatty acids. Briefly, we incubated both lung supernatant and sodium phosphate buffer at $37^{\circ} \mathrm{C}$ for $1 \mathrm{~h}$, and the mixture was centrifuged after being precipitated with 10\% TCA (trichloroacetic acid). Then, 1\% TBA was added to the supernatant, and the mixture was placed in the boiling water for $15 \mathrm{~min}$. The absorbance was read at $532 \mathrm{~nm}$ and expressed in $\mathrm{nmol} / \mathrm{mg}$ protein using a molar extinction coefficient of $156,000 \mathrm{M} / \mathrm{cm}$. The determination of total proteins was carried out using the methodology established by the Labtest ${ }^{\circledR}$ brand commercial kit.

\subsection{Assessment of Superoxide Dismutase (SOD) Tissue Activity}

The organs that were removed were washed thrice in potassium chloride solution $(1.15 \% \mathrm{KCl})$, and then homogenized $(1: 5 w / v)$ with a solution containing $\mathrm{KCl}$, phenylmethylsulfonylfluoride (PMSF $100 \mathrm{~m} / \mathrm{mol}$ ), and Triton solution (10\%). Homogenates were centrifuged at $3000 \times \mathrm{g}$ for $10 \mathrm{~min}$ at $4{ }^{\circ} \mathrm{C}$, and the supernatant was stored at $-80^{\circ} \mathrm{C}$ for the determination of oxidative stress markers (TBARS and SH). Superoxide dismutase (SOD) activity was based on the inhibition of the auto-oxidation of epinephrine to adenochrome in the presence of SOD ( $\mathrm{pH}$ 10.2) [17]. Briefly, $20 \mathrm{~mL}$ of epinephrine $(5 \mathrm{mg} / \mathrm{mL})$ was added to the assay mixture containing $10 \mathrm{~mL}$ of bovine catalase $(0.4 \mathrm{U} / \mathrm{mL})$ and $62.5 \mathrm{mM}$ sodium carbonate-sodium bicarbonate buffer. One unit of SOD is defined as the enzyme required to inhibit the quantity of adenochrome generated by $50 \%$. The absorbance was recorded at $480 \mathrm{~nm}$.

\subsection{Assessment of Catalase (CAT) Tissue Activity}

In the samples prepared as previously described, CAT activity was assessed using the method previously reported by Bahri et al. (2020) [17] at $240 \mathrm{~nm}$. Briefly, the reaction mixture included $\mathrm{H}_{2} \mathrm{O}_{2}$ in $0.019 \mathrm{M}, 0.05 \mathrm{M}$ phosphate buffer ( $\mathrm{pH}$ 7), and $0.03 \mathrm{~mL}$ of lung sample. CAT activity was expressed as $\mu$ mole of $\mathrm{H}_{2} \mathrm{O}_{2}$ consumed $/ \mathrm{min} / \mathrm{mg}$ of protein.

\subsection{Histological Procedures and Assessment of the Histological Grading of Bleomycin-Induced Lung Fibrosis}

For histological analysis, the formalin-fixed lung samples were dehydrated in ethanol, diaphanized in xylene, and embedded in paraffin. Then, 20 serial histological sections were obtained from the lung sample. Four of them were stained in hematoxylin/eosin (HE) and six in Masson's trichrome (5.0 $\mu \mathrm{m}$ thick). The other 10 histological sections $(3.0 \mu \mathrm{m}$ thick) were used for the immunohistochemical study. All of the histological analysis was blindly conducted by two examiners previously calibrated. In order to assess the severity and the extension of lung fibrosis, a semi-quantitative grading system described by Ashcroft et al. (1988) [30] and modified by Hubner et al. (2008) [31] was used. Briefly, 10 histological fields $\left(400 \times, 0.025 \mathrm{~mm}^{2}\right)$ of each section (five from the upper and five from the lower halves of the left lungs) were analyzed and classified as described in Table 2. Data were expressed as median and interquartile intervals.

\subsection{Analysis of the Immunohistochemical Expression of $\alpha$-SMA and TGF- $\beta$ in the Lung Tissue}

Both of the immunohistochemical reactions were performed on five 3.0- $\mu \mathrm{m}$-thick sections of paraffin-embedded tissues. Antigen retrieval was performed with citrate buffer solution ( $\mathrm{pH}$ 6.0) for $15 \mathrm{~min}$ in an electric pressure cooker. Endogenous peroxidase activity was suppressed with $10 \% \mathrm{H}_{2} \mathrm{O}_{2}$, in five cycles of 5 min each. Subsequently, the sections were incubated with primary antibodies for $2 \mathrm{~h}$. Primary antibodies included: anti- $\alpha-$ SMA (clone h-CD, dilution 1:400; Dako, Glostrup, Denmark) and anti-TGF- $\beta$ (clone 17, 1:50 dilution; Novocastra Laboratories, Newcastle upon Tyne, UK). Immunohistochemical staining was performed with Advance (Dako, Hamburg, Germany), following the manufacturer's instructions. Slides were then exposed to diaminobenzidine tetrahydrochloride (DAB; Sigma-Aldrich, St Louis, MO, USA) and counterstained with Carazzi's hematoxylin. Twenty histological fields $\left(800 \times, 0.0625 \mathrm{~mm}^{2}\right), 10$ from the upper and 10 from the lower halves of the lung histological sections, were randomly selected and recorded, and positive 
cells (identified by cytoplasmic brown stain) were counted. Data were expressed as mean number of positive cells/histological field $\left(0.0625 \mathrm{~mm}^{2}\right)$.

Table 2. Modified Ashcroft scale for histological grading of lung damage.

\begin{tabular}{|c|c|}
\hline Grade of Fibrosis & Modified Scale \\
\hline 0 & $\begin{array}{l}\text { Alveolar Septa: No fibrotic burden at the flimsiest small fibers in some alveolar walls } \\
\text { Lung structure: Normal lung }\end{array}$ \\
\hline 1 & $\begin{array}{l}\text { Alveolar Septa: Isolated gentle fibrotic changes (septum } \leq 3 \times \text { thicker than normal) } \\
\text { Lung structure: Alveoli partly enlarged and rarefied, but no fibrotic masses present. }\end{array}$ \\
\hline 2 & $\begin{array}{l}\text { Alveolar Septa: Clearly fibrotic changes (septum }>3 \times \text { thicker than normal) with not-like formation but not } \\
\text { connected to each other } \\
\text { Lung structure: Alveoli partly enlarged and rarefied, but no fibrotic masses. }\end{array}$ \\
\hline 3 & $\begin{array}{l}\text { Alveolar Septa: Contiguous fibrotic walls (septum }>3 \times \text { thicker than normal) predominantly in whole } \\
\text { microscopic field } \\
\text { Lung structure: Alveoli partly enlarged and rarefied, but no fibrotic masses. }\end{array}$ \\
\hline 4 & $\begin{array}{l}\text { Alveolar Septa: Variable } \\
\text { Lung structure: Single fibrotic masses ( } \leq 10 \% \text { microscopic field })\end{array}$ \\
\hline 5 & $\begin{array}{l}\text { Alveolar Septa: Variable } \\
\text { Lung structure: Confluent fibrotic masses ( }>10 \% \text { and } \leq 50 \% \text { of microscopic field). Lung structure severely } \\
\text { damaged but still preserved. }\end{array}$ \\
\hline 6 & $\begin{array}{l}\text { Alveolar Septa: Variable, most not existent } \\
\text { Lung structure: Large contiguous fibrotic masses (>50\% of microscopic field). Lung architecture mostly not } \\
\text { preserved. }\end{array}$ \\
\hline 7 & $\begin{array}{l}\text { Alveolar Septa: Non-existent } \\
\text { Lung structure: Alveoli nearly obliterated with fibrous masses but still up to five air bubbles. }\end{array}$ \\
\hline 8 & $\begin{array}{l}\text { Alveolar Septa: Non-existent } \\
\text { Lung structure: Microscopic field with complete obliteration with fibrotic masses. }\end{array}$ \\
\hline
\end{tabular}

\subsection{Statistical Analysis}

Statistical analysis was performed in Graph Pad Prism software, version 7.0 (GraphPad Software, San Diego, CA, USA). Analysis of the normality of distribution of data was performed using the Shapiro-Wilk test. Gaussian data (expressed as mean \pm standard mean error) were analyzed using analysis of variance (ANOVA) and Tukey's multiple comparisons test. Non-gaussian data (expressed as median and interquartile amplitude) were analyzed using the Kruskal-Wallis test and Dunn's multiple comparisons test. The significance level adopted for all of the tests was $5 \%(p<0.05)$.

\section{Results}

The essential oil of Cymbopogon winterianus presented as a colorless oil, with a distinct odor and a yield of $1.14 \%$. The identification of the components in the sample is described in Table 3 and included 47 compounds. Among them, 17 oxygenated monoterpenes, 13 oxygenated sesquiterpenes, 7 sesquiterpenes, 5 monoterpenes, 2 aldehydes, 2 ketones, and 1 acid. Citronellal (32.61\%), geraniol (22.83\%), and citronellol (14.37\%) were the main oxygenated monoterpenes found. 
Table 3. Chemical composition and retention indices of the chemical constituents of the EOCW.

\begin{tabular}{|c|c|c|c|}
\hline $\mathrm{RT}(\min )^{a}$ & Compounds $b$ & $(\%)^{c}$ & RI $^{d}$ \\
\hline 6.4 & 3-Hexanone, 2-methyl- & 0.01 & 871 \\
\hline 11.0 & 5-Hepten-2-one, 6-methyl- & 0.03 & 987 \\
\hline 11.1 & $\beta$-Myrcene & 0.10 & 990 \\
\hline 12.7 & Limonene & 3.21 & 1027 \\
\hline 13.9 & Melonal & 0.16 & 1053 \\
\hline 15.4 & Terpinolene & 0.05 & 1087 \\
\hline 16.0 & Linalool & 1.17 & 1101 \\
\hline 16.5 & cis-Rose oxide & 0.05 & 1110 \\
\hline 17.2 & trans-Rose oxide & 0.03 & 1127 \\
\hline 18.1 & Isopulegol & 1.55 & 1145 \\
\hline 18.7 & Citronellal & 32.61 & 1159 \\
\hline 19.2 & Isopulegol & 0.10 & 1170 \\
\hline 19.6 & 4-Terpineol & 0.07 & 1178 \\
\hline 19.8 & Carane, 4,5-epoxy-, trans & 0.06 & 1183 \\
\hline 20.2 & $\alpha$-Terpineol & 0.09 & 1191 \\
\hline 20.3 & cis-4-Decenal & 0.05 & 1194 \\
\hline 20.8 & Decanal & 0.20 & 1206 \\
\hline 22.1 & Citronellol & 14.37 & 1233 \\
\hline 22.5 & Neral & 1.32 & 1242 \\
\hline 23.4 & Geraniol & 22.83 & 1262 \\
\hline 23.8 & Geranial & 1.56 & 1272 \\
\hline 25.9 & Citronellic acid & 0.26 & 1320 \\
\hline 27.4 & Citronellol acetate & 0.93 & 1354 \\
\hline 27.6 & Phenol, 4-allyl-2-methoxy- & 0.94 & 1359 \\
\hline 28.7 & Geranyl acetate & 1.14 & 1384 \\
\hline 29.0 & $\beta$-Element & 0.56 & 1392 \\
\hline 30.1 & Caryophyllene & 0.04 & 1419 \\
\hline 31.5 & Humulene & 0.07 & 1454 \\
\hline 32.5 & Naphthalene, 1,2,4a,5,6,8a-hexahydro-4,7-dimethyl-1-(1-methylethyl)- & 0.07 & 1477 \\
\hline 32.7 & Germacrene D & 0.97 & 1482 \\
\hline 33.4 & $\alpha$-Muurolene & 0.30 & 1501 \\
\hline 33.6 & $\delta$-Guaiene & 0.56 & 1506 \\
\hline 34.0 & $\alpha$-Amorphene & 0.24 & 1514 \\
\hline 34.4 & $\beta$-Cadinene & 1.16 & 1524 \\
\hline 35.4 & $o$-Menth-8-ene-4-methanol, $\alpha, \alpha$-dimethyl-1-vinyl-, $(1 \mathrm{~S}, 2 \mathrm{~S}, 4 \mathrm{R})-(-)-$ & 3.64 & 1552 \\
\hline 36.4 & trans-Sesquisabinene hydrate & 1.02 & 1577 \\
\hline 36.7 & Caryophyllene oxide & 0.14 & 1584 \\
\hline 38.1 & Eudesmol & 0.49 & 1621 \\
\hline 38.4 & $\alpha$-Acorenol & 0.46 & 1629 \\
\hline 38.5 & $\alpha$-Eudesmol & 1.26 & 1633 \\
\hline 38.9 & $\alpha$-Muurolol & 1.79 & 1644 \\
\hline 39.0 & Cadinol & 0.45 & 1648 \\
\hline 39.2 & $\beta$-Eudesmol & 0.67 & 1652 \\
\hline 39.4 & $\alpha$-Cadinol & 2.95 & 1657 \\
\hline 41.5 & $(\mathrm{Z}, \mathrm{E})$-Farnesol & 0.04 & 1716 \\
\hline 41.7 & (E,E)-Farnesol & 0.21 & 1723 \\
\hline
\end{tabular}

${ }^{a}$ RT, retention time; ${ }^{b}$ compounds listed in order of elution from an DB-5MS column; ${ }^{c}$ percentage based on FID peak area normalization;

${ }^{\mathrm{d}} \mathrm{RI}$, retention index, calculated using the Van den Dool and Kratz (1963) equation [29].

Table 4 shows the animals' body weight on the first and on day 28. Only the group EOCW200 showed a gain in body weight over the experimental period, although this was significantly lower than observed in the Sham group $(p<0.001)$. On the other hand, the Vehicle group and all of the other treated groups (EOCW50, EOCW100 and DFC) showed statistically similar percentages of body weight loss $(p>0.05)$. 
Table 4. Body weight variation of animals according to the experimental group.

\begin{tabular}{|c|c|c|c|c|c|c|}
\hline Body Weight & Sham & Vehicle & EOCW 50 & EOCW 100 & EOCW 200 & DFC \\
\hline Initial (g) & $174 \pm 11.33$ & $236.8 \pm 20.7$ & $213.33 \pm 20.81$ & $200.25 \pm 12.01$ & $179.83 \pm 9.04$ & $174.66 \pm 6.31$ \\
\hline Final $(\mathrm{g})$ & $183.4 \pm 9.55$ & $228.6 \pm 15.14$ & $206.66 \pm 20.64$ & $195 \pm 7.02$ & $182.5 \pm 8.31$ & $172.5 \pm 6.22$ \\
\hline Body weight gain (\%) & $5.17 \pm 1.60^{\mathrm{a}}$ & $-3.46 \pm 2.32^{b}$ & $-3.24 \pm 1.21^{b}$ & $-2.63 \pm 2.85^{b}$ & $1.42 \pm 0.55^{c}$ & $-1.27 \pm 0.48^{b, c}$ \\
\hline
\end{tabular}

Data are expressed as means \pm SEM. Different letters $(a, b, c)$ in the same line represent significantly different values between them $(p<0.05$; ANOVA and Tukey's multiple comparisons test).

Table 5 shows the assessment of hematological parameters in the groups at the end of the experimental time. Although significant differences were observed in some parameters of both red and white cells of the peripheral blood, all of the values remained within the normal range of the reference. These findings suggest that no relevant status of hematological change was observed under the experimental conditions in the bleomycininduced pulmonary fibrosis model.

Table 5. Hematological parameters of the animals submitted to the experiment.

\begin{tabular}{|c|c|c|c|c|c|c|c|}
\hline \multirow{2}{*}{ Hematological Parameters } & \multirow{2}{*}{ Sham } & \multirow{2}{*}{ Vehicle } & \multicolumn{3}{|c|}{ EOCW (mg/kg) } & \multirow{2}{*}{ DFC } & \multirow{2}{*}{$\begin{array}{c}\text { Reference } \\
\text { Range * }\end{array}$} \\
\hline & & & 50 & 100 & 200 & & \\
\hline Total leukocytes $\left(\times 10^{3} / \mu \mathrm{L}\right)$ & $4.7 \pm 0.6^{\mathrm{a}}$ & $3.1 \pm 1.2^{b}$ & $5.0 \pm 0.3^{a}$ & $4.5 \pm 0.6^{\mathrm{a}}$ & $6.1 \pm 1.4^{\mathrm{a}}$ & $3.6 \pm 0.4^{b}$ & $2.3-9.9$ \\
\hline Red blood cells $\left(\times 10^{3} / \mu \mathrm{L}\right)$ & $8.0 \pm 1.0^{\mathrm{a}}$ & $5.8 \pm 0.7^{\mathrm{b}}$ & $6.1 \pm 1.7^{\mathrm{b}}$ & $6.1 \pm 0.9^{b}$ & $7.6 \pm 1.2^{\mathrm{a}}$ & $9.0 \pm 0.4^{\mathrm{a}}$ & $5.2-8.8$ \\
\hline Hematocrit $(\%)$ & $51.8 \pm 1.9^{a}$ & $38.4 \pm 4.0^{b}$ & $40.5 \pm 0.70^{b}$ & $39.2 \pm 1.70^{b}$ & $46.0 \pm 2.4^{\mathrm{a}}$ & $52.8 \pm 2.9^{a}$ & $27.2-48.5$ \\
\hline Hemoglobin (g/dL) & $15.7 \pm 0.9$ & $13.7 \pm 1.7$ & $13.6 \pm 0.9$ & $13.9 \pm 0.8$ & $14.6 \pm 1.0$ & $16.0 \pm 0.8$ & $11.1-17.1$ \\
\hline Platelets $\left(\times 10^{3} / \mu \mathrm{L}\right)$ & $1.0 \pm 0.2$ & $1.3 \pm 0.7$ & $1.0 \pm 0.4$ & $1.2 \pm 0.2$ & $0.9 \pm 0.1$ & $0.8 \pm 0.1$ & $0.76-1.31$ \\
\hline
\end{tabular}

* Reference range values available in Lima et al. (2014) [32]. Different letters $(a, b)$ in the same line express significantly different values between them (ANOVA and multiple comparison Tukey's test, $p<0.05$ ).

As demonstrated in Figure 1, a significant increase in the BALF total leukocytes counts was observed in group Vehicle in comparison with Sham $(p<0.001)$. Although a significant decrease in the leukocytes counts was determined by the administration of EOCW at 50 and $100 \mathrm{mg} / \mathrm{kg}(p<0.001)$, the leukocyte counts remained significantly above the Sham group $(p<0.001)$. However, the treatment with EOCW at $200 \mathrm{mg} / \mathrm{kg}$ and deflazacort not only promoted a significant decrease in the BALF leukocyte counts in comparison with groups Vehicle, EOCW50, and EOCW100 $(p<0.001)$, but also reduced them to values statistically comparable to the Sham group $(p>0.05)$. Differential analysis showed increase in neutrophils, lymphocytes, and macrophages counts in Vehicle $(p<0.001)$. All of the treatment protocols tested in this study similarly promoted significant reduction of neutrophils and macrophages to the basal ranges observed in Sham $(p<0.001)$, and there was no significant difference between them $(p>0.05)$. Regarding lymphocytes, however, although EOCW at 50 and $100 \mathrm{mg} / \mathrm{kg}$ determined a significant decrease in the cell counts $(p<0.001)$, only the administration of EOCW at $200 \mathrm{mg} / \mathrm{kg}$ and deflazacort promoted a reduction intense enough to bring the values to the basal ranges seen in Sham $(p>0.05)$.

The tissue contents of MDA were assessed by the thiobarbituric acid reactive substance test (TBARs) in samples of lung tissue from animals with bleomycin-induced pulmonary fibrosis (Figure 2A). Increased levels of MDA were observed in group Vehicle $(439.8 \pm 26.7 \mathrm{nmol} / \mathrm{mg})$ in comparison with group Sham $(211.5 \pm 23.1 \mathrm{nmol} / \mathrm{mg}$; $p<0.001)$. Significant reduction of MDA tissue levels in comparison with group Vehicle was observed in groups EOCW $50(333.8 \pm 35.1 \mathrm{nmol} / \mathrm{mg} ; p<0.05)$, EOCW100 $(256.6 \pm 4.1 \mathrm{nmol} / \mathrm{mg} ; p<0.001)$, EOCW200 (262.6 $\pm 7.2 \mathrm{nmol} / \mathrm{mg} ; p<0.001)$, and DFC $(344.8 \pm 10.8 \mathrm{nmol} / \mathrm{mg} ; p<0.05)$. In addition, the MDA levels observed in groups EOCW100 and EOCW200 were statistically comparable to group Sham $(p>0.05)$. A significant decrease in SOD activity was observed in Vehicle $(82.3 \pm 2.0 \mathrm{U} / \mathrm{min} / \mathrm{mg} ; p<0.001)$, EOCW50 (92.8 $\pm 1.9 \mathrm{U} / \mathrm{min} / \mathrm{mg} ; p<0.05)$, and DFC $(82.3 \pm 2.0 \mathrm{U} / \mathrm{min} / \mathrm{mg} ; p<0.001)$ groups in comparison with that of Sham $(75.5 \pm 1.5 \mathrm{U} / \mathrm{min} / \mathrm{mg})$. However, the SOD activity in groups EOCW100 $(94.8 \pm 0.4 \mathrm{U} / \mathrm{min} / \mathrm{mg})$ and EOCW200 $(97.7 \pm 4.8 \mathrm{U} / \mathrm{min} / \mathrm{mg})$ 
was statistically comparable to Sham $(p>0.05)$ (Figure 2B). Although no significant difference was observed between the values of CAT activity obtained in groups Vehicle $(27.5 \pm 1.5 \mu \mathrm{Mol} / \mathrm{min} / \mathrm{mg})$, EOCW50 (31.8 $\pm 0.9 \mu \mathrm{Mol} / \mathrm{min} / \mathrm{mg}), \quad$ EOCW100 $(28.5 \pm 0.8 \mu \mathrm{Mol} / \mathrm{min} / \mathrm{mg})$, EOCW200 $(28.4 \pm 3.5 \mu \mathrm{Mol} / \mathrm{min} / \mathrm{mg})$, and DFC $(28.5 \pm 2.3 \mu \mathrm{Mol} / \mathrm{min} / \mathrm{mg})(p>0.05)$, they all significantly decreased in comparison with the Sham group $(36.4 \pm 1.2 \mu \mathrm{Mol} / \mathrm{min} / \mathrm{mg})(p<0.05$; Figure $2 \mathrm{C})$.

A)

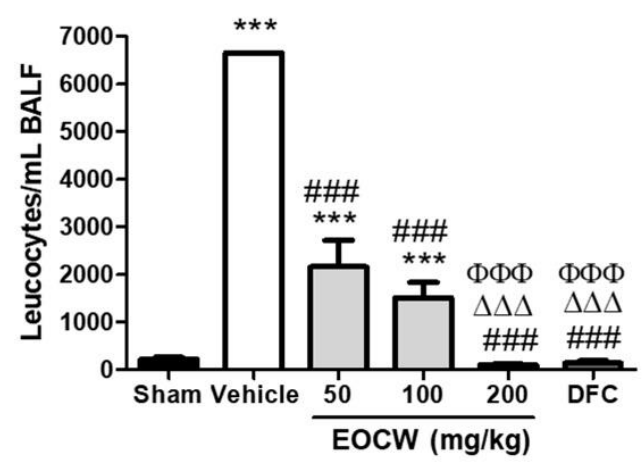

C)

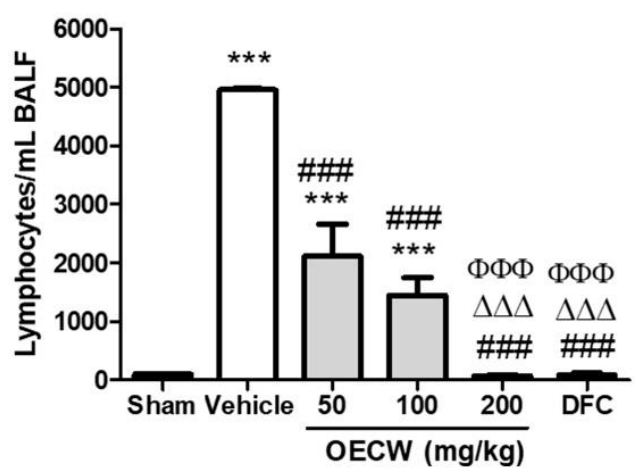

B)

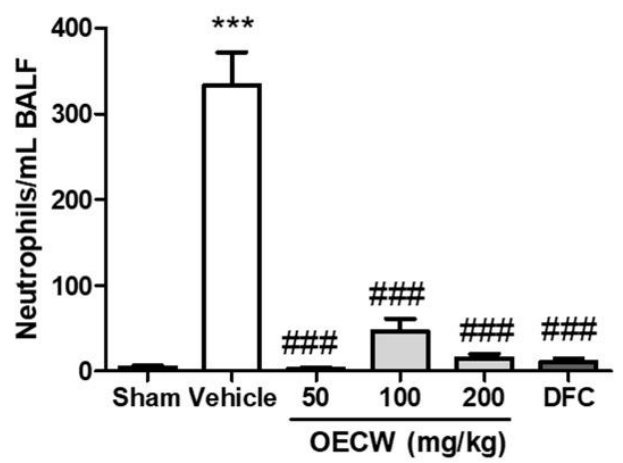

D)

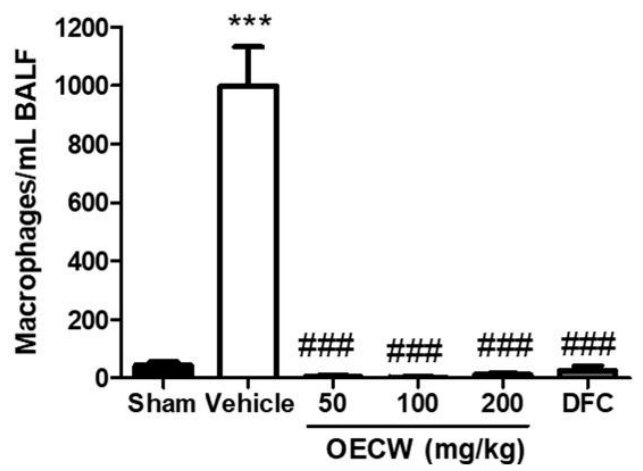

Figure 1. Values obtained from bronchoalveolar lavage cells: (A) total cells; (B) neutrophils; (C) lymphocytes, and (D) macrophages. Significant differences compared to the Sham group are expressed with ${ }^{* * *} p<0.001$; significant differences compared to the Vehicle group are expressed as \#\#\# $p<0.001$; significant differences compared to the OECW 50 group are expressed as $\Delta \Delta \Delta p<0.001$; significant differences compared to the OECW 100 group are expressed as $\Phi \Phi \Phi p<0.001$. (Kruska-Wallis, followed by Dunn's multiple comparisons test).

BLM induced marked morphologic changes of the lung tissue in the Vehicle group, compared with the Sham group, including: (i) intense inflammatory infiltration, with lymphocytes and alveolar macrophages in the lung interstitium; (ii) severe thickening of the alveolar septa due to intense fibrosis, leading to partial or total obliteration of the pulmonary alveoli (alveolar collapse); (iii) intense peribronchial and peribronchiolar fibrosis; (iv) formation of air bubbles in the middle of the obliterated parenchyma, resembling the honeycomb aspect of hives (alveolar "honeycombing"); and (v) hyperemia and hemorrhage, associated with areas of marked interstitial edema. The treatment with EOCW attenuated BLM-induced lung damage as follows: (i) reduced inflammatory/phagocytic infiltration; (ii) fewer damaged alveoli, including less alveolar obliteration and honeycombing; and (iii) reduced alveolar thickening and peribronchial and peribronchiolar fibrosis. In addition, as observed in DFC (deflazacort-treated group), the pulmonary changes observed in groups EOCW100 and EOCW200 were markedly attenuated to almost normal levels, suggesting that the doses of 100 and $200 \mathrm{mg} / \mathrm{kg}$ were more effective in inhibiting PF at a histological level (Figure 3A). As demonstrated in Figure 3B, the severity of the Ashcroft's histological grading of pulmonary fibrosis induced by bleomycin in the Vehicle-treated group $(6 ; 5-7)$ was significantly reduced by the use of deflazacort $(4,1-5 ; p<0.001)$ and EOCW at $100(5$, 
$4-6 ; p<0.01)$ and $200 \mathrm{mg} / \mathrm{kg}(5,4-5 ; p<0.001)$ but not with $50 \mathrm{mg} / \mathrm{kg}(6,5-6 ; p>0.05)$. Furthermore, only the dose of $200 \mathrm{mg} / \mathrm{kg}$ of the essential oil promoted histological grading attenuation of the pulmonary damage comparable to deflazacort $(p>0.05)$.

A)

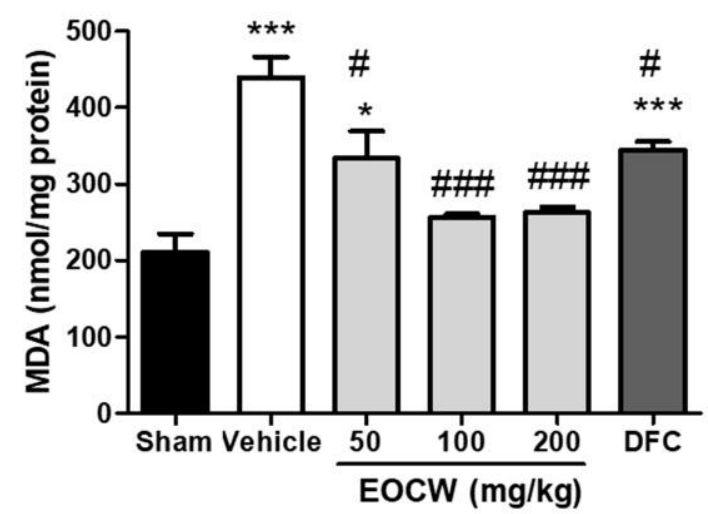

B)

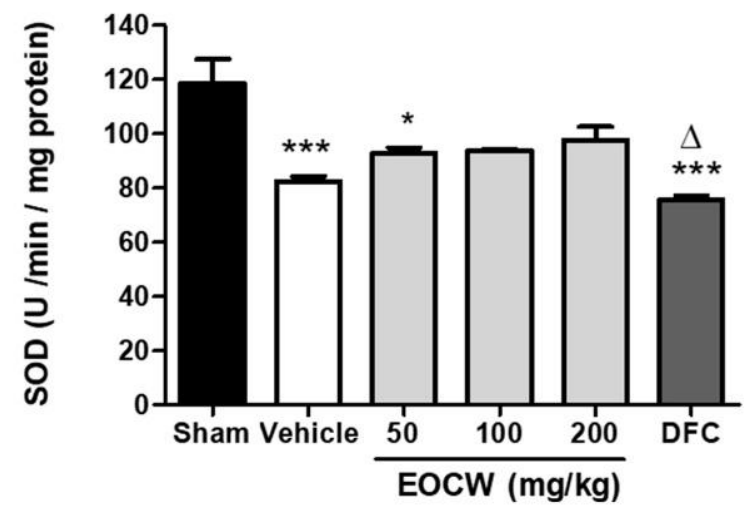

C)

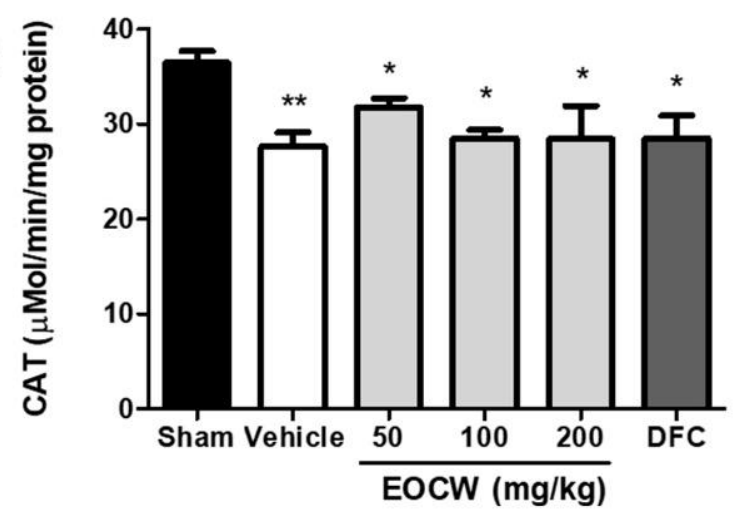

Figure 2. Effect of EOCW on oxidative stress parameters in bleomycin-induced lung fibrosis: (A) MDA production, (B) SOD activity, and (C) CAT activity. Significant differences compared to the group Sham are expressed as ${ }^{*} p<0.05$, ${ }^{* *} p<0.01$ and ${ }^{* * *} p<0.001$; significant differences compared to the Vehicle group are expressed as \# $p<0.05$ and \#\#\# $p<0.001$; significant differences compared to the EOCW50 group are expressed as $\Delta p<0.05$.

Figure 4 shows the cytoplasmic positivity pattern of the immunohistochemical expression of $\alpha$-SMA and TGF- $\beta$ antigens in paraffin-embedded pulmonary tissue of the experimental groups. In group Sham, $\alpha$-SMA expression in the pulmonary interstitial space and alveolar septa walls was mild $\left(1.6 \pm 0.1\right.$ cells $\left./ 0.0625 \mu^{2}\right)$. Although strong positivity was observed in peribronchiolar and perivascular areas, these positive cells were interpreted as smooth muscle cells or eventual pericytes instead of myofibroblasts. No positivity was observed in the alveolar epithelial cells. Group Vehicle exhibited significantly increased $\alpha$-SMA expression in interstitial cells and type II pneumocytes lining alveolar spaces $\left(5.3 \pm 0.3\right.$ cells $\left./ 25 \mu^{2}, p<0.05\right)$. Significant reduction of $\alpha$-SMA expression was observed in all of the groups undergone treatment with $C$. winterianus essential oil and deflazacort in comparison with the Vehicle group $(p<0.001)$. No significant difference was observed between the groups treated with EOCW $100\left(2.9 \pm 0.2\right.$ cells $\left./ 0.0625 \mu^{2}\right)$, EOCW $200\left(2.7 \pm 0.2\right.$ cells $\left./ 0.0625 \mu \mathrm{m}^{2}\right)$, and DFC $\left(2.3 \pm 0.3\right.$ cells $\left./ 25 \mu \mathrm{m}^{2}\right)(p>0.01)$. 


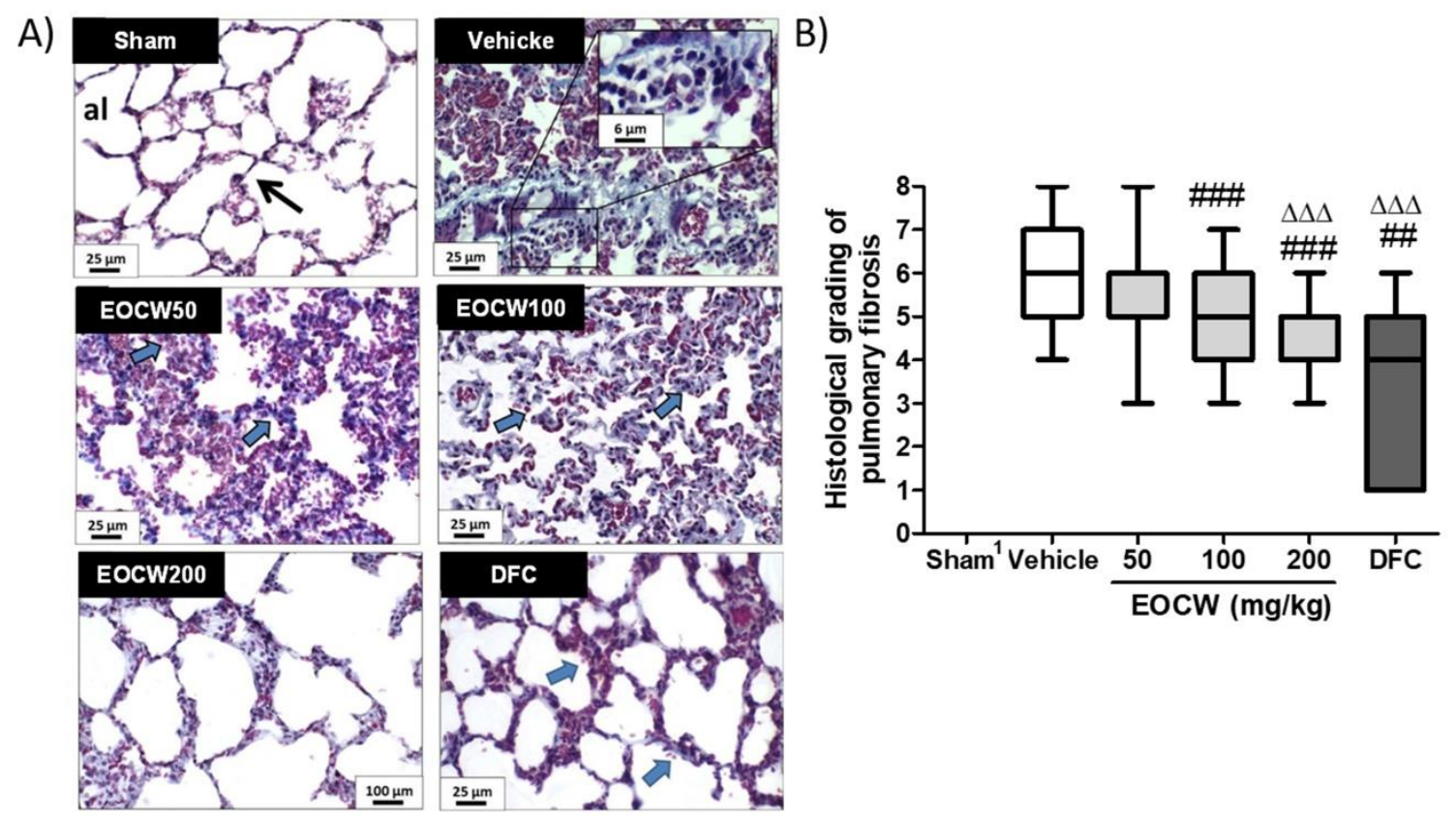

Figure 3. (A) Histological features observed in the pulmonary tissue of the experimental groups. Typical regular alveolar spaces (al), with thin septa, are seen in group Sham, whereas groups Vehicle and EOCW50 show thickened septa and fibrotic collapsed alveoli (hyperplasia of type II pneumocytes in detail). Partially obliterated alveoli and alveolar septa of variable thickness are seen in group EOCW100. Wider and more regular alveoli, with thin septa, are observed in groups EOCW200 and DFC (Masson's trichrome, 400×). (B) Assessment of the modified Ashcroft scale of histological gradation of the bleomycin-induced pulmonary fibrosis in the experimental groups. Data are expressed as median, interquartile range, and maximum and minimum values. Significant differences compared to group Vehicle are expressed as \#\# $p<0.01$ and \#\#\# $p<0.001$; significant differences compared to group EOCW50 are expressed as $\Delta \Delta \Delta p<0.001$ (Kruskal-Wallis and Dunn's multiple comparisons test).

In the Sham group, cytoplasmic immunohistochemical expression of TGF- $\beta$ was observed in alveolar macrophages, endothelial cells, and interstitial fibroblasts. However, in the groups subjected to bleomycin-induced pulmonary fibrosis, positivity was also seen in bronchiolar epithelium and type I/II pneumocytes. As expected, the immunohistochemical expression of TGF- $\beta$ in all of the BLM groups was greater than in the Sham group $\left(0.55 \pm 0.15\right.$ cells $\left./ 0.0625 \mu \mathrm{m}^{2} ; p<0.01\right)$. The groups Vehicle $\left(3.17 \pm 0.21\right.$ cells $\left./ 0.0625 \mu \mathrm{m}^{2}\right)$ and EOCW $50\left(2.661 \pm 0.25\right.$ cells $\left./ 0.0625 \mu^{2}\right)$ presented the greatest counts of positive cells, which were both greater than in group EOCW $200\left(1.70 \pm 0.22\right.$ cells $\left./ 0.0625 \mu \mathrm{m}^{2}\right)(p<0.001$ and $p<0.05)$ and DFC $\left(1.40 \pm 0.18\right.$ cells $\left./ 0.0625 \mu \mathrm{m}^{2}\right)(p<0.001$ and $p<0.001)$. Although the intermediate dose of the essential oil of $C$. winterianus $(100 \mathrm{mg} / \mathrm{kg})$ promoted a significant decrease in the immunoexpression of TGF- $\beta\left(2.44 \pm 0.19\right.$ cells $\left./ 0.0625 \mu \mathrm{m}^{2}\right)$ in comparison with group Vehicle $(p<0.05)$, it was still significantly greater than in $200 \mathrm{mg} / \mathrm{kg}$ of the essential oil $(p<0.05)$ and DFC $(p<0.001)$. 


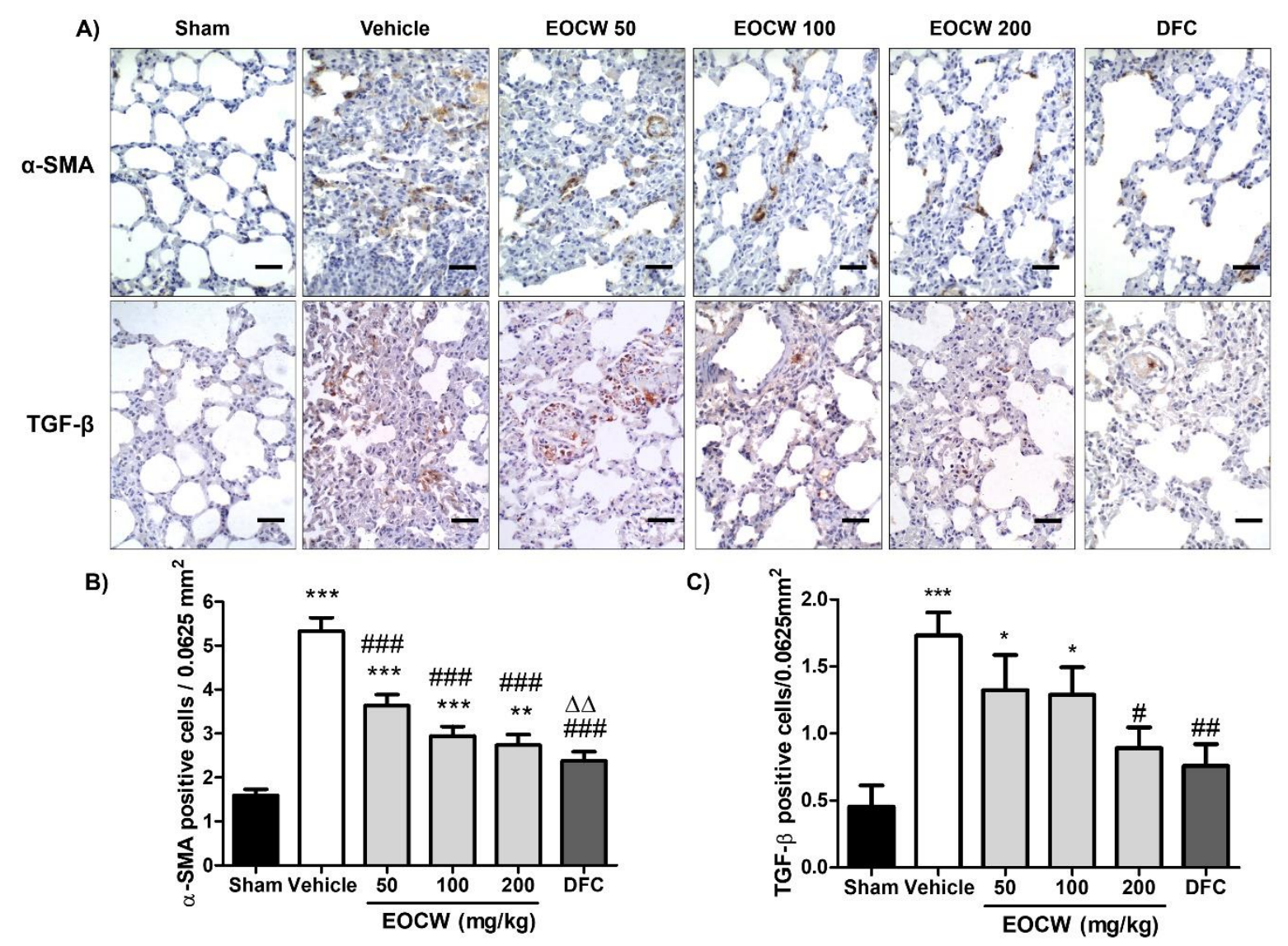

Figure 4. (A) Cytoplasmic positivity pattern of immunohistochemical expression of $\alpha$-SMA and TGF- $\beta$ in group Sham and subjected to bleomycin-induced pulmonary fibrosis (Masson's trichrome, $400 \times$ ). (B) Assessment of the immunohistochemical expression of $\alpha$-SMA and (C) TGF- $\beta$ in the pulmonary tissue of the experimental groups. Significant differences compared to group Sham are expressed as ${ }^{*} p<0.05,{ }^{* *} p<0.01$ and ${ }^{* * *} p<0.001$; compared to group Vehicle are expressed as $\# p<0.05$, \#\# $p<0.01$ and \#\#\# $p<0.001$; compared to EOCW50 are expressed as $\Delta \Delta p<0.01$ (ANOVA and Tukey's multiple comparisons test).

\section{Discussion}

Deflazacort is a synthetic glucocorticoid that has few adverse effects on glucose and calcium metabolism, whose pharmacologic safety profile is similar to that of other glucocorticoids. This drug presents strong immunosuppressive and antifibrotic activity [33] and has been used in the treatment of pulmonary fibrosis [34,35]. In addition, the choice for deflazacort in the current study was also based on two other facts: (i) the least adverse effects compared to other drugs; and (ii) its rapid absorption by the gastrointestinal tract when administered orally and immediate hepatic conversion to 21-hydroxideflazacort, its main active metabolite [36].

In this study, the chemical composition of the EOCW was identified by GC-MS and the monoterpenes citronellal, geraniol, and citronellol were the major chemical compounds found. The very same major constituents of EOCW have been previously reported in samples of northeastern Brazil, from Sergipe [37] and Pernambuco [38]. There are some variations in the chemical composition of the oils obtained from plants of the same genus, depending on the soil, location, and seasons when the leaves were collected [39-41]. Hence, this could explain other major chemical compositions found in EOCW, as the one reported in the Anand region, northeast India, whose main constituents were citronellol (34.25\%), linalool $(27.47 \%)$, citronellal (11.52\%), and emelol (11.15\%) [42]. Based on the antioxidant [22-24], anti-inflammatory [19,25], and antifibrotic [26] properties of this essential oil, we designed the first study on the potential activity of the EOCW on bleomycin-induced pulmonary fibrosis in a rodent model. In addition, the doses $(50,100$, and $200 \mathrm{mg} / \mathrm{kg}$ ) 
were chosen according to the study previously conducted by Leite et al. (2011) [19], using EOCW of the same region, with a similar major chemical composition.

As body weight variations are commonly used to monitor an animal's health status during the progression of diseases, including bleomycin-induced lung injury [43], we assessed the body weight gain in the animals at the end of the time course of the experiment. We found that the administration of bleomycin to induce pulmonary fibrosis promoted loss of body weight in rats over time, which has been also demonstrated in other studies using a similar experimental model $[44,45]$. Chemotherapeutics, such as bleomycin, causes significant loss of body weight due to the reduction in both muscle mass and as a result of deleterious effects on the gastrointestinal tract [46], which could explain the data obtained in the current study. Only the treatment with EOCW at $200 \mathrm{mg} / \mathrm{kg}$ prevented body weight loss, and we hypothesized that such an effect might be related to the high contents of the chemical constituents of the essential oil at this dose. Geraniol administered orally is a modulator of the intestinal microbiota, which is able to improve the relative abundance of Collinsella and Faecalibacterium, well-known bacteria of health-promoting butyrate [47]. Butyrate is a major metabolite in colonic lumen derived from bacterial fermentation of dietary fiber, responsible for about $70 \%$ of energy from the colonocytes [48]. Hence, as butyrate is currently considered a critical mediator of the colonic inflammatory response, it is possible to suppose that the beneficial effects associated with EOCW at $200 \mathrm{mg} / \mathrm{kg}$ administration might be related to the high content of geraniol, which was not achieved in lower doses. In addition, the administration of deflazacort provided no significant improvement in the body weight loss. This could be explained by the fact that although the pulmonary inflammatory-induced exudative changes and intense fibrosis can increase the lung weight $\sim$ two-fold, it has not been considered enough to significantly mask the animal's body weight loss [49]. However, further investigations are necessary to fully clarify these theories.

Inhibition of the immune system has been associated with the development of pulmonary fibrosis [50], which led us to assess the hematological parameters of the animals in the current study. Although apparently some significant differences were observed in both red and white cells counts (Table 3), all of the values were within the normal range, and, therefore, they were considered spurious. Similar data have been previously reported [51,52]. It is possible that this result might be related to the experimental model used in the current study, in which the chemotherapeutic agent is applied only once by direct tracheal instillation, producing only mild systemic damage. Hence, these findings are suggestive that the assessment of the peripheral blood red and white cells counts can be unhelpful to evaluate the course of the disease.

BALF analysis, on the other hand, has shown to determine the severity of alveolitis, and, for this reason, it has been used as a parameter to assess the magnitude of inflammatory damage caused by bleomycin on pulmonary tissues in rodents [53]. Bleomycin intratracheal instillation in group Vehicle determined a significant increase in leukocytes in BALF. Supporting our findings, acute alveolitis and interstitial inflammation, and consequent increased leukocyte recruitment, have been previously reported to occur after intratracheal administration of bleomycin in rodents [54]. Although the exchange between inflammation and fibrosis begins to occur between days 8 and 14, the presence of plasma exudation and, consequently, leukocytes in BALF, between 21 and 28 days has been reported [55,56], as observed in the current study. Hence, these data suggest the long-term persistence of the aggression and the inflammatory response in the lung tissues. In addition, the increase in total proteins has been demonstrated in BALF 28 days after intratracheal bleomycin instillation, which supports the hypothesis of persistent pulmonary exudation [57].

A differential analysis of leukocytes in BALF has been used to characterize the nature of the persistent inflammatory response [58]. We found that both polymorphonuclear (neutrophils) and mononuclear cells (lymphocytes and macrophages) increased in BALF, just as previously reported [57]. This leukocyte profile was expected as the BALF analysis was performed on day 28 , when the typical acute phase of the inflammatory response 
had already occurred. Treatment with EOCW reduced the inflammation in BALF in a dose-dependent pattern. In addition, the therapeutic effect of EOCW at $200 \mathrm{mg} / \mathrm{kg}$ was statistically similar to deflazacort. These findings suggest that EOCW minimizes bleomycininduced alveolitis, and that, at a dose of $200 \mathrm{mg} / \mathrm{kg}$, this effect is comparable to the corticotherapy. In a previous study, EOCW at 50, 100, and $200 \mathrm{mg} / \mathrm{kg}$ have demonstrated dose-dependent anti-inflammatory properties in rodents [37], which helps to support the hypothesis that the beneficial effects of this natural product might be at least partially associated to the inhibition of the inflammation.

To investigate the role of the antioxidant properties of EOCW in attenuating bleomycininduced pulmonary fibrosis, we assessed the levels of MDA produced by lipid peroxidation in situ, as well as SOD and CAT activity. We found increased levels of MDA and decreased activity of SOD and CAT in animals subjected to bleomycin-induced pulmonary fibrosis treated with Vehicle only in comparison to Sham, as also observed in previous investigations $[59,60]$. Bleomycin downregulates phosphorylation expression of mitogen-activated protein kinases (MAPKs), which increases the production of nitric-oxide synthase and NADPH oxidase. The level of MDA, a by-product of lipid peroxidation, is closely related to the oxidative damage of cell membranes that occurs in response to bleomycin-induced lung injury [59]. The tissue activity of the antioxidant enzymes SOD and CAT are some of the most important antioxidant defenses against oxidative stress caused by BLM [61], which could explain the decreased activity of SOD and CAT as observed in the current study. The results presented here suggest that the bleomycin-induced pulmonary fibrosis in the murine model is associated to intense oxidative stress. Hence, oxidative stress is a key pathological process in the development and progression of pulmonary fibrosis, the inhibition of oxidative stress and enhancement of antioxidative ability could supposedly alleviate pulmonary fibrosis [62]. In fact, the treatment with EOCW (100 and $200 \mathrm{mg} / \mathrm{kg}$ ) reduced MDA levels and increased SOD activity, suggesting antioxidant activity. Supporting our findings, the use of geraniol, one of the major chemical compounds of EOCW, has proved to reduce the lipid peroxidation levels in rat brain tissue homogenates (25-40\%) [63]. Geraniol has also been reported to induce activation of nuclear factor erythroid 2-related factor 2 (Nrf2). As upon oxidative stress, Nrf2 detaches from its cytoplasmic inhibitor protein and transfers into the nucleus to activate various antioxidant enzymes (e.g., glutathione peroxidase and superoxide dismutase), the activation of the Nrf2 pathway could be involved in the maintenance of the cellular defense mechanism through antioxidant properties [64]. Furthermore, previous studies have demonstrated that the administration of essential oil of Rosa damascena Mill L., whose major constituents are citronellol (38.04\%) and geraniol $(26.32 \%)$, promotes moderate inhibition of MDA production and increase in SOD activity in injured brain tissue [65]. So, although the precise mechanisms underlying the antioxidant activity of EOCW are not fully clarified, we hypothesized that the EOCW ability to inhibit or reduce the oxidative stress and inflammatory response could be involved in the attenuation of the tissue damage that occurs in bleomycin-induced pulmonary fibrosis.

The occurrence of severe pathological alterations in the lung tissue in response to bleomycin intratracheal instillation is well established [66], and, for this reason, we investigated the effects of EOCW on the prevention or attenuation of the histological changes of the injured lungs. Hyperplasia of type II pneumocytes, massive infiltration of alveolar macrophages, and thickening of the alveolar septa, leading to total or partial obliteration of the alveoli, were some of the morphological features found in the bleomycin-injured lungs, which are in accordance with other studies [60,67]. As the modified Ashcroft scale has been widely used to grade the severity of the histological damage associated to bleomycininduced pulmonary fibrosis [31], it was applied in the current study. Attenuation of the pulmonary histological damage resulting from the administration of EOCW at doses of 100 and $200 \mathrm{mg} / \mathrm{kg}$ was found in the current study, which might be possibly related to the anti-inflammatory and antioxidant properties of the major chemical compounds of the essential oil [68-70]. In fact, citronellal has shown to inhibit 5-lipoxygenase and nitric 
oxide production [23], whereas citronellol inhibits COX-2 and prostaglandin-E2 (PGE2) expression, and impairs TNF- $\alpha$-induced neutrophil adhesion, as well as increases SOD production, reduces NO release, and decreases inducible nitric oxide synthase activity [24]. Furthermore, geraniol inhibits prostaglandin E2 and tumor necrosis factor alpha (TNF$\alpha$ ) [71], and has been considered a potential drug to be used in inflammatory lung diseases, where oxidative stress was a critical point [22]. Therefore, the control of the inflammatory response and oxidative stress will be instrumental to prevent or attenuate the progression of the histological damages that features the pulmonary fibrosis. Supporting this theory, the progression of the histological damage was also achieved using corticosteroids (deflazacort). At $50 \mathrm{mg} / \mathrm{kg}$, the EOCW was unsuccessful in preventing BLM-induced pulmonary fibrosis, supposedly due to the low concentrations of the chemical compounds at this dose. In addition, although the results obtained with $100 \mathrm{mg} / \mathrm{kg}$ were significantly better than using the Vehicle only, they were not comparable with deflazacort. Taken together, these data pointed at a dose-dependent effect played by EOCW on the prevention of the pulmonary fibrosis induced by BLM.

There are significant parallels between inflammatory response and myofibroblast differentiation in fibrosis of different tissues [72], and myofibroblasts play a key role in fibrogenesis via the accumulation of an excessive amount of extracellular matrix in lungs with idiopathic PF $[14,73]$. Hence, the development of effective therapeutic interventions against idiopathic PF have focused on the reduction or prevention of myofibroblast overdifferentiation [74]. As in histological sections, myofibroblasts can be easily marked and quantified by the immunohistochemical detection of cytoplasmic filaments of $\alpha$ smooth muscle actin ( $\alpha$-SMA) [75]; we assessed the pulmonary immunohistochemical expression of $\alpha$-SMA-positive cells in the current study. Increased counts of $\alpha$-SMA positive myofibroblasts were found in animals with bleomycin-induced pulmonary fibrosis, which is in accordance with previous studies using the same experimental model [54,76]. These data suggest that the pathogenesis of pulmonary fibrosis can be associated with increased recruitment of myofibroblasts.

Although the precise origin of myofibroblasts in pulmonary fibrosis is controversial, studies have suggested that they likely derive from TGF- $\beta$ activated preexisting peribronchial and perivascular adventitial fibroblasts and pericytes, migration of smooth muscle cells from adjacent areas, as well as EMT of type II pneumocytes and endothelial cells [77,78]. As a response of EMT, these immotile epithelial cells are converted into motile mesenchymal cells with a myofibroblastic phenotype, characterized by the loss of expression of typical epithelial markers (e.g., E-cadherin) and increased expression of mesenchymal and contractile markers (e.g., vimentin and $\alpha$-smooth muscle actin, respectively) [79]. There is recent evidence that EMT-derived myofibroblasts present higher rates of proliferation and collagen production than conventional fibroblasts, and, therefore, they play an important role in the pathogenesis of idiopathic PF [10]. The major cytokine involved in the myofibroblast differentiation, irrespective to its origin (mesenchymal or epithelial), is TGF- $\beta$ released by $\mathrm{T}$ cells, macrophages, activated endothelial cells and smooth muscle cells, and fibroblasts under stress conditions [80]. In addition, enhanced in situ release of TGF- $\beta 1$ promotes deregulation of the Wnt- $\beta$-catenin signaling pathways, which confers resistance to apoptosis and proliferative advantages to myofibroblasts. Thus, an imbalance between profibrotic and antifibrotic mediators is created, maintaining an environment supportive of exaggerated myofibroblast activity and chronic fibroproliferation [2].

Myofibroblast differentiation was reduced in response to the treatment with EOCW and deflazacort. The precise mechanisms underlying the negative modulation of myofibroblast differentiation by EOCW is not fully clear. Inhibition of in vitro and in vivo myofibroblastic differentiation potential through blockage of TGF- $\beta 1$ expression exerted by corticosteroids in palmar fibromatosis-derived stem cells has been previously reported [81]. As the corticoid used in the current study also reduced myofibroblastic differentiation, this inhibitory activity might have been a result of TGF- $\beta 1$ suppression. Inflammatory cells and other epithelial and mesenchymal cells activated by inflammatory cytokines are the 
major sources of TGF- $\beta$. Therefore, drugs such as steroids and cyclooxygenase inhibitors have been considered effective in reducing inflammatory cytokines, such as TGF- $\beta$, and consequently attenuate collagen deposition [82].

As far as we know, no previous study has focused on the inhibitory effects of the major chemical compounds of EOCW on myofibroblastic differentiation, but we hypothesized that it might be related to their anti-inflammatory activity and suppression of TGF- $\beta$ expression-just as demonstrated with corticosteroids. To prove this theory right, the immunohistochemical expression of TGF- $\beta$ was assessed in histological sections of lungs with BLM-induced pulmonary fibrosis. As expected, untreated animals presented the greatest counts of TGF- $\beta$-expressing cells, which agrees with other studies previously reported $[56,82,83]$. The significant decrease in pulmonary cells expressing TGF- $\beta$ in EOCW-treated groups at 100 and $200 \mathrm{mg} / \mathrm{kg}$, as well as in the deflazacort-treated group, is fully supported by the analysis of $\alpha$-SMA-positive cells, attesting to the close relation between this cytokine and myofibroblast differentiation. In addition, as also observed in the current study, other investigations have demonstrated the attenuation of the severity of the pulmonary fibrosis through the use of drugs that suppress TGF- $\beta$ expression, such as halofuginone, crocin [79], and amitriptyline [9]. Oral administration of angiotensin 1-7, a heptapeptide with anti-inflammatory activity, in a model of BLM-induced lung fibrosis in mice, decreased inflammation and collagen deposition, as well as ameliorated lung function [83], whereas the incubation of human lung fibroblasts with A779, an angiotensin 1-7 agonist, has shown to reduce levels of TGF- $\beta$ and collagen type [84]. These data seem to support the relation between anti-inflammatory agents and downregulation of TGF- $\beta$, with consequent reduction of fibrosis.

\section{Conclusions}

Oral administration of EOCW attenuates the histological changes associated to the progression and severity of bleomycin-induced pulmonary fibrosis in rodents, likely due to inhibition of TGF- $\beta$ immunohistochemical expression and the consequent decrease in the myofibroblast differentiation. We also provide evidence that this antifibrotic activity could be associated with the anti-inflammatory and antioxidant properties of the essential oil. Therefore, EOCW is a potential candidate to be used as a phytotherapeutic in further clinical trials for the treatment of pulmonary fibrosis.

Author Contributions: Conceptualization, methodology and writing-original draft preparation: L.A.T., D.D.-A., I.J.C.-N., A.A.R., J.L.S., C.S.E., A.M.O.S., J.K.S. and J.L.S.C.; validation and formal analysis: L.A.T., D.D.-A., I.J.C.-N., A.A.R., J.L.S.C., C.S.E., A.M.O.S., J.K.S., J.L.S.C., J.C.C., P.S., E.B.S. and R.L.C.d.A.-J.; investigation and data curation, L.A.T., D.D.-A., I.J.C.-N., A.A.R., J.L.S.C., C.S.E., A.M.O.S., J.K.S. and J.L.S.C.; writing—review and editing, supervision, project administration, and funding acquisition: J.C.C., P.S., E.B.S. and R.L.C.d.A.-J. All authors have made a substantial contribution to the work. All authors have read and agreed to the published version of the manuscript.

Funding: This research was financed by the Coordenação Aperfeiçoamento de Pessoal de Nivel Superior (CAPES), Fundação de Amparo à Pesquisa do Estado de Sergipe (FAPITEC), and Conselho Nacional de Desenvolvimento Científico e Tecnológico (CNPq). EBS wishes to acknowledge the sponsorship of the project UIDB/04469/2020 (strategic fund) from the Portuguese Science and Technology Foundation, Ministry of Science and Education (FCT/MEC) through national funds, and was co-financed by FEDER, under the Partnership Agreement PT2020.

Institutional Review Board Statement: Animal experiments were approved by the Ethics Committee on Animal Research of the Tiradentes University (CEUA/UNIT) through Opinion No. \#020917. Ethics principles Use of Laboratory Animals of the Brazilian Society of Laboratory Animal Science (SBCAL/COBEA) were followed together with the 3R principles of the EU Directive 2010/63/EU transferred to the national Decreto-Lei 113/2013 (in Portugal), the 2001/83/EC and 86/609/EEC (on the protection of animals used for experimental and other scientific), and the Amsterdam protocol on animal protection and welfare of 1997 FP7 Decision number 1982/2006EC.

Informed Consent Statement: Not applicable. 
Data Availability Statement: Data available from authors upon request.

Conflicts of Interest: The authors declare no conflict of interest.

\section{References}

1. Martinez, F.J.; Collard, H.R.; Pardo, A.; Raghu, G.; Richeldi, L.; Selman, M.; Swigris, J.J.; Taniguchi, H.; Wells, A.U. Idiopathic pulmonary fibrosis. Nat. Rev. Dis. Primers 2017, 3, 17074. [CrossRef] [PubMed]

2. Sgalla, G.; Iovene, B.; Calvello, M.; Ori, M.; Varone, F.; Richeldi, L. Idiopathic pulmonary fibrosis: Pathogenesis and management. Respir. Res. 2018, 19, 32. [CrossRef] [PubMed]

3. Jafri, S.; Ahmed, N.; Saifullah, N.; Musheer, M. Epidemiology and Clinico-radiological features of Interstitial Lung Diseases. Pak. J. Med. Sci. 2020, 36, 365-370. [CrossRef] [PubMed]

4. Meyer, K.C. Pulmonary fibrosis, part I: Epidemiology, pathogenesis, and diagnosis. Expert Rev. Respir. Med. 2017, 11, 343-359. [CrossRef] [PubMed]

5. Bahri, S.; Ben Ali, R.; Abidi, A.; Jameleddine, S. The efficacy of plant extract and bioactive compounds approaches in the treatment of pulmonary fibrosis: A systematic review. Biomed. Pharmacother. 2017, 93, 666-673. [CrossRef]

6. Evans, C.M.; Fingerlin, T.E.; Schwarz, M.I.; Lynch, D.; Kurche, J.; Warg, L.; Yang, I.V.; Schwartz, D.A. Idiopathic Pulmonary Fibrosis: A Genetic Disease That Involves Mucociliary Dysfunction of the Peripheral Airways. Physiol. Rev. 2016, 96, 1567-1591. [CrossRef]

7. Raghu, G.; Remy-Jardin, M.; Myers, J.L.; Richeldi, L.; Ryerson, C.J.; Lederer, D.J.; Behr, J.; Cottin, V.; Danoff, S.K.; Morell, F.; et al. Diagnosis of Idiopathic Pulmonary Fibrosis. An Official ATS/ERS/JRS/ALAT Clinical Practice Guideline. Am. J. Respir. Crit. Care Med. 2018, 198, e44-e68. [CrossRef]

8. Salton, F.; Volpe, M.C.; Confalonieri, M. Epithelial-Mesenchymal Transition in the Pathogenesis of Idiopathic Pulmonary Fibrosis. Medicina 2019, 55, 83. [CrossRef]

9. Zaafan, M.A.; Haridy, A.R.; Abdelhamid, A.M. Amitriptyline attenuates bleomycin-induced pulmonary fibrosis: Modulation of the expression of NF- $\beta \beta$, iNOS, and Nrf2. Naunyn-Schmiedeberg's Arch. Pharmacol. 2019, 392, 279-286. [CrossRef]

10. Li, L.; Li, Q.; Wei, L.; Wang, Z.; Ma, W.; Liu, F.; Shen, Y.; Zhang, S.; Zhang, X.; Li, H.; et al. Dexamethasone combined with berberine is an effective therapy for bleomycin-induced pulmonary fibrosis in rats. Exp. Ther. Med. 2019, 18, 2385-2392. [CrossRef]

11. Yue, X.; Shan, B.; Lasky, J.A. TGF- $\beta$ : Titan of Lung Fibrogenesis. Curr. Enzym. Inhib. 2010, 6. [CrossRef]

12. Warshamana, G.S.; Pociask, D.A.; Fisher, K.J.; Liu, J.-Y.; Sime, P.J.; Brody, A.R. Titration of non-replicating adenovirus as a vector for transducing active TGF-beta1 gene expression causing inflammation and fibrogenesis in the lungs of C57BL/6 mice. Int. J. Exp. Pathol. 2002, 83, 183-201. [CrossRef] [PubMed]

13. Moustakas, A.; Heldin, C.-H. Mechanisms of TGF $\beta$-Induced Epithelial-Mesenchymal Transition. J. Clin. Med. 2016, 5, 63. [CrossRef] [PubMed]

14. Dong, J.; Ma, Q. Myofibroblasts and lung fibrosis induced by carbon nanotube exposure. Part. Fibre Toxicol. 2016, 13, 60. [CrossRef] [PubMed]

15. Sontake, V.; Gajjala, P.R.; Kasam, R.K.; Madala, S.K. New therapeutics based on emerging concepts in pulmonary fibrosis. Expert Opin. Ther. Targets 2019, 23, 69-81. [CrossRef] [PubMed]

16. Gharaee-Kermani, M.; Gyetko, M.R.; Hu, B.; Phan, S.H. New insights into the pathogenesis and treatment of idiopathic pulmonary fibrosis: A potential role for stem cells in the lung parenchyma and implications for therapy. Pharm. Res. 2007, 24, 819-841. [CrossRef]

17. Bahri, S.; Ben Ali, R.; Nahdi, A.; Mlika, M.; Abdennabi, R.; Jameleddine, S. Salvia officinalis attenuates bleomycin-induced oxidative stress and lung fibrosis in rats. Nutr. Cancer 2020, 72, 1135-1145. [CrossRef]

18. Sun, L.; Mao, M.; Yan, Z.; Zuo, C.; Zhang, X. A Chinese Traditional Therapy for Bleomycin-Induced Pulmonary Fibrosis in Mice. Can. Respir. J. 2018, 2018, 8491487. [CrossRef] [PubMed]

19. Leite, B.L.S.; Souza, T.T.; Antoniolli, Â.R.; Guimarães, A.G.; Siqueira, R.S.; Quintans, J.S.S.; Bonjardim, L.R.; Alves, P.B.; Blank, A.F.; Botelho, M.A.; et al. Volatile constituents and behavioral change induced by Cymbopogon winterianus leaf essential oil in rodents. Afr. J. Biotechnol. 2011, 10, 8312-8319.

20. Sharma, R.; Rao, R.; Kumar, S.; Mahant, S.; Khatkar, S. Therapeutic Potential of Citronella Essential Oil: A Review. Curr. Drug Discov. Technol. 2019, 16, 330-339. [CrossRef] [PubMed]

21. Quintans-Júnior, L.J.; Souza, T.T.; Leite, B.S.; Lessa, N.M.; Bonjardim, L.R.; Santos, M.R.; Alves, P.B.; Blank, A.F.; Antoniolli, A.R. Phythochemical screening and anticonvulsant activity of Cymbopogon winterianus Jowitt (Poaceae) leaf essential oil in rodents. Phytomedicine Int. J. Phytother. Phytopharm. 2008, 15, 619-624. [CrossRef]

22. Tiwari, M.; Kakkar, P. Plant derived antioxidants-Geraniol and camphene protect rat alveolar macrophages against t-BHP induced oxidative stress. Toxicol. In Vitro 2009, 23, 295-301. [CrossRef]

23. Tsai, M.-L.; Lin, C.-D.; Khoo, K.A.; Wang, M.-Y.; Kuan, T.-K.; Lin, W.-C.; Zhang, Y.-N.; Wang, Y.-Y. Composition and Bioactivity of Essential Oil from Citrus grandis (L.) Osbeck 'Mato Peiyu' Leaf. Molecules 2017, 22, 2154. [CrossRef] [PubMed]

24. Santos, P.L.; Matos, J.; Picot, L.; Almeida, J.; Quintans, J.S.S.; Quintans-Júnior, L.J. Citronellol, a monoterpene alcohol with promising pharmacological activities-A systematic review. Food Chem. Toxicol. 2019, 123, 459-469. [CrossRef]

25. Jayachandran, M.; Chandrasekaran, B.; Namasivayam, N. Geraniol attenuates fibrosis and exerts anti-inflammatory effects on diet induced atherogenesis by NF-kB signaling pathway. Eur. J. Pharmacol. 2015, 762, 102-111. [CrossRef] [PubMed] 
26. Qin, D.-M.; Wang, X.-B.; Zou, N.; Han, C.; Xu, J. Gas Chromatography-Mass Spectrometry (GC-MS) Analysis of the Volatile Oil of Cichorium Glandulosum Boiss et Huet and its Effects on Carbon Tetrachloride-Induced Liver Fibrosis in Rats. Med. Sci. Monit. 2019, 25, 3591-3604. [CrossRef]

27. Silveira, G.d.O.; Loddi, S.; de Oliveira, C.D.R.; Zucoloto, A.D.; Fruchtengarten, L.V.G.; Yonamine, M. Headspace solid-phase microextraction and gas chromatography-Mass spectrometry for determination of cannabinoids in human breast milk. Forensic Toxicol. 2017, 35, 125-132. [CrossRef]

28. Sparkman, O.D. Identification of essential oil components by gas chromatography/quadrupole mass spectroscopy Robert P. Adams. J. Am. Soc. Mass Spectrom. 2005, 16, 1902-1903. [CrossRef]

29. van Den Dool, H.; Kratz, P.D. A generalization of the retention index system including linear temperature programmed gas-liquid partition chromatography. J. Chromatogr. A 1963, 11, 463-471. [CrossRef]

30. Ashcroft, T.; Simpson, J.M.; Timbrell, V. Simple method of estimating severity of pulmonary fibrosis on a numerical scale. J. Clin. Pathol. 1988, 41, 467-470. [CrossRef]

31. Hübner, R.H.; Gitter, W.; El Mokhtari, N.E.; Mathiak, M.; Both, M.; Bolte, H.; Freitag-Wolf, S.; Bewig, B. Standardized quantification of pulmonary fibrosis in histological samples. BioTechniques 2008, 44, 507-511, 514-517. [CrossRef] [PubMed]

32. Lima, C.M.; Lima, A.K.; Melo, M.G.D.; Dória, G.A.A.; Serafini, M.R.; Albuquerque-Júnor, R.L.C.; Araújo, A.A.S. Valores de referência hematológicos e bioquímicos de ratos (Rattus novergicus linhagem Wistar) provenientes do biotério da Universidade Tiradentes. Scientia Plena 2014, 10.

33. Gonzalez-Perez, O.; Luquin, S.; Garcia-Estrada, J.; Ramos-Remus, C. Deflazacort: A glucocorticoid with few metabolic adverse effects but important immunosuppressive activity. Adv. Ther. 2007, 24, 1052-1060. [CrossRef]

34. de Castro Pereira, C.A.; Baddini-Martinez, J.A.; Baldi, B.G.; de Oliveira Jezler, S.F.; Rubin, A.S.; Rufino Alves, R.L.; Alves Zonzin, G.; Quaresma, M.; Trampisch, M.; Rabahi, M.F. Segurança e tolerabilidade de Nintedanibe em pacientes com fibrose pulmonar idiopática no Brasil. J. Bras. Pneumol. 2019, 45, e20180414. [CrossRef] [PubMed]

35. National Clinical Guideline Centre. National Institute for Health and Care Excellence: Clinical Guidelines. In Diagnosis and Management of Suspected Idiopathic Pulmonary Fibrosis: Idiopathic Pulmonary Fibrosis; Royal College of Physicians: London, UK, 2013.

36. Ding, W.; Ding, L.; Li, W.B.; Pan, H.; Lin, H.D. Pharmacokinetics of deflazacort tablets in healthy Chinese volunteers. Yao Xue Xue Bao Acta Pharm. Sin. 2014, 49, 921-926.

37. Leite, B.L.; Bonfim, R.R.; Antoniolli, A.R.; Thomazzi, S.M.; Araújo, A.A.; Blank, A.F.; Estevam, C.S.; Cambui, E.V.; Bonjardim, L.R.; Albuquerque, R.L., Jr.; et al. Assessment of antinociceptive, anti-inflammatory and antioxidant properties of Cymbopogon winterianus leaf essential oil. Pharm. Biol. 2010, 48, 1164-1169. [CrossRef]

38. Silva, C.T.S.; Wanderley-Teixeira, V.; Cunha, F.M.; Oliveira, J.V.; Dutra, K.A.; Navarro, D.M.A.F.; Teixeira, A.A.C. Effects of citronella oil (Cymbopogon winterianus Jowitt ex Bor) on Spodoptera frugiperda (J. E. Smith) midgut and fat body. Biotech. Histochem. 2018, 93, 36-48. [CrossRef]

39. Okoh, S.O.; Okoh, O.O.; Okoh, A.I. Seasonal variation of volatile oil composition and antioxidant property of aerial parts of Syzygium paniculatum Gaertn. grown in the Eastern Cape, South Africa. Nat. Prod. Res. 2019, 33, 2276-2280. [CrossRef] [PubMed]

40. Zribi, I.; Bleton, J.; Moussa, F.; Abderrabba, M. GC-MS analysis of the volatile profile and the essential oil compositions of Tunisian Borago Officinalis L.: Regional locality and organ dependency. Ind. Crop. Prod. 2019, 129, 290-298. [CrossRef]

41. Niyibituronsa, M.; Onyango, A.N.; Gaidashova, S.; Imathiu, S.; Ming, Z.; Ruinan, Y.; Weiqi, Z.; XiuPin, W.; Qi, Z.; Zhaowei, Z.; et al. Evaluation of Five Essential Oils by Gas Chromatography-Mass Spectrometry and their Effect on Fungal Growth Inhibition and Sensory Acceptability of Soymilk. J. Food Res. 2020, 9, 36-47. [CrossRef]

42. Solanki, K.P.; Desai, M.A.; Parikh, J.K. Sono hydrodistillation for isolation of citronella oil: A symbiotic effect of sonication and hydrodistillation towards energy efficiency and environment friendliness. Ultrason. Sonochem. 2018, 49, 145-153. [CrossRef]

43. Barbayianni, I.; Ninou, I.; Tzouvelekis, A.; Aidinis, V. Bleomycin Revisited: A Direct Comparison of the Intratracheal MicroSpraying and the Oropharyngeal Aspiration Routes of Bleomycin Administration in Mice. Front. Med. 2018, 5, 269. [CrossRef]

44. Jost, R.T.; Dias, H.B.; Krause, G.C.; de Souza, R.G.; de Souza, T.R.; Nuñez, N.K.; Dos Santos, F.G.; Haute, G.V.; da Silva Melo, D.A.; Pitrez, P.M.; et al. Fructose-1,6-Bisphosphate Prevents Bleomycin-Induced Pulmonary Fibrosis in Mice and Inhibits the Proliferation of Lung Fibroblasts. Inflammation 2018, 41, 1987-2001. [CrossRef]

45. Dias, H.B.; de Oliveira, J.R.; Donadio, M.V.F.; Kimura, S. Fructose-1,6-bisphosphate prevents pulmonary fibrosis by regulating extracellular matrix deposition and inducing phenotype reversal of lung myofibroblasts. PLoS ONE 2019, 14, e0222202. [CrossRef]

46. Hajjaji, N.; Couet, C.; Besson, P.; Bougnoux, P. DHA effect on chemotherapy-induced body weight loss: An exploratory study in a rodent model of mammary tumors. Nutr. Cancer 2012, 64, 1000-1007. [CrossRef]

47. Rizzello, F.; Ricci, C.; Scandella, M.; Cavazza, E.; Giovanardi, E.; Valerii, M.C.; Campieri, M.; Comparone, A.; De Fazio, L.; Candela, M.; et al. Dietary geraniol ameliorates intestinal dysbiosis and relieves symptoms in irritable bowel syndrome patients: A pilot study. BMC Complement. Altern. Med. 2018, 18, 338. [CrossRef]

48. Zeng, H.; Lazarova, D.L.; Bordonaro, M. Mechanisms linking dietary fiber, gut microbiota and colon cancer prevention. World J. Gastrointest. Oncol. 2014, 6, 41-51. [CrossRef] [PubMed]

49. Cowley, P.M.; Roberts, C.R.; Baker, A.J. Monitoring the Health Status of Mice with Bleomycin-induced Lung Injury by Using Body Condition Scoring. Comp. Med. 2019, 69, 95-102. [CrossRef] [PubMed]

50. Zhu, J.; Kaplan, A.M.; Goud, S.N. Immunologic alterations in bleomycin-treated mice: Role of pulmonary fibrosis in the modulation of immune responses. Am. J. Respir. Crit. Care Med. 1996, 153, 1924-1930. [CrossRef] [PubMed] 
51. Arun, K.; Vankatachalam, V.V.; Deepak, U.; Tiwari, V.K.; Aakash, S. Combined Effect of N-Acetyl Cysteine and Clarithromycin on Bleomycin Induced Pulmonary Fibrosis. Int. Biol. Biomed. J. 2018, 4, 14-23.

52. Ding, Y.; Xiao, L.; Chen, R.; Qing, Y.; Gao, Y.; Jiang, Q.; Chen, X. Efficacy and Safety of Inhaled Anti-Fibrotic Peptide HTPEP-001 in Rat Models. In A64. Therapeutics, Drug Delivery, and Tissue Engineering. American Journal of Respiratory and Critical Care Medicine 2020; American Thoraic Society: New York, NY, USA, 2020; Volume 201, p. A2286. [CrossRef]

53. Qiu, M.; An, M.; Bian, M.; Yu, S.; Liu, C.; Liu, Q. Terrestrosin D from Tribulus terrestris attenuates bleomycin-induced inflammation and suppresses fibrotic changes in the lungs of mice. Pharm. Biol. 2019, 57, 694-700. [CrossRef]

54. Lucattelli, M.; Fineschi, S.; Selvi, E.; Garcia Gonzalez, E.; Bartalesi, B.; De Cunto, G.; Lorenzini, S.; Galeazzi, M.; Lungarella, G. Ajulemic acid exerts potent anti-fibrotic effect during the fibrogenic phase of bleomycin lung. Respir. Res. 2016, 17, 49. [CrossRef] [PubMed]

55. Ding, W.; Zhang, X.-Y.; Pan, M.; Zhao, B.; Chen, C.; Niu, Z.-H.; Huang, C.-L.; Li, Y.-Y.; Fan, X.-M.; Ma, Y.-M.; et al. Interleukin17A promotes the formation of inflammation in the lung tissues of rats with pulmonary fibrosis. Exp Ther. Med 2015, 10, 491-497. [CrossRef]

56. Kim, Y.-S.; Li, Q.; Youn, H.-Y.; Kim, D.Y. Oral Administration of Chitosan Attenuates Bleomycin-induced Pulmonary Fibrosis in Rats. In Vivo 2019, 33, 1455-1461. [CrossRef] [PubMed]

57. Zaghloul, M.S.; Said, E.; Suddek, G.M.; Salem, H.A. Crocin attenuates lung inflammation and pulmonary vascular dysfunction in a rat model of bleomycin-induced pulmonary fibrosis. Life Sci. 2019, 235, 116794. [CrossRef] [PubMed]

58. Kabel, A.M.; Estfanous, R.S.; Alrobaian, M.M. Targeting oxidative stress, proinflammatory cytokines, apoptosis and toll like receptor 4 by empagliflozin to ameliorate bleomycin-induced lung fibrosis. Respir. Physiol. Neurobiol. 2020, 273, 103316. [CrossRef] [PubMed]

59. Li, L.; Cai, L.; Zheng, L.; Hu, Y.; Yuan, W.; Guo, Z.; Li, W. Gefitinib Inhibits Bleomycin-Induced Pulmonary Fibrosis via Alleviating the Oxidative Damage in Mice. Oxid. Med. Cell. Longev. 2018, 2018, 8249693. [CrossRef]

60. Mansouri, N.; Willis, G.R.; Fernandez-Gonzalez, A.; Reis, M.; Nassiri, S.; Mitsialis, S.A.; Kourembanas, S. Mesenchymal stromal cell exosomes prevent and revert experimental pulmonary fibrosis through modulation of monocyte phenotypes. JCI Insight 2019, 4, e128060. [CrossRef] [PubMed]

61. Yang, D.X.; Qiu, J.; Zhou, H.H.; Yu, Y.; Zhou, D.L.; Xu, Y.; Zhu, M.Z.; Ge, X.P.; Li, J.M.; Lv, C.J.; et al. Dihydroartemisinin alleviates oxidative stress in bleomycin-induced pulmonary fibrosis. Life Sci. 2018, 205, 176-183. [CrossRef]

62. Qian, Y.; Han, Q.; Zhao, X.; Song, J.; Cheng, Y.; Fang, Z.; Ouyang, Y.; Yuan, W.E.; Fan, C. 3D melatonin nerve scaffold reduces oxidative stress and inflammation and increases autophagy in peripheral nerve regeneration. J. Pineal Res. 2018, 65, e12516. [CrossRef]

63. Prasad, S.N.; Muralidhara, M. Analysis of the antioxidant activity of geraniol employing various in vitro models: Relevance to neurodegeneration in diabetic neuropathy. Asian J. Pharm. Clin. Res. 2017, 10, 101-105. [CrossRef]

64. El-Emam, S.Z.; Soubh, A.A.; Al-Mokaddem, A.K.; Abo El-Ella, D.M. Geraniol activates Nrf-2/HO-1 signaling pathway mediating protection against oxidative stress-induced apoptosis in hepatic ischemia-reperfusion injury. Naunyn-Schmiedeberg's Arch. Pharmacol. 2020, 393, 1849-1858. [CrossRef]

65. Sahakyan, N.; Petrosyan, M.; Trchounian, A. Some peculiarities of essential oil of Damask Rose growing in high altitude Armenian Landscapes. Proc. YSU B Chem. Biol. Sci. 2020, 54, 68-74. [CrossRef]

66. Liu, T.; De Los Santos, F.G.; Phan, S.H. The Bleomycin Model of Pulmonary Fibrosis. In Fibrosis; Rittié, L., Ed.; Methods in Molecular Biology; Humana Press: Totowa, NJ, USA, 2017; Volume 1627, pp. 27-42. [CrossRef]

67. Ruscitti, F.; Ravanetti, F.; Essers, J.; Ridwan, Y.; Belenkov, S.; Vos, W.; Ferreira, F.; KleinJan, A.; van Heijningen, P.; Van Holsbeke, C.; et al. Longitudinal assessment of bleomycin-induced lung fibrosis by Micro-CT correlates with histological evaluation in mice. Multidiscip. Respir. Med. 2017, 12, 8. [CrossRef] [PubMed]

68. Ferraz, M.C.; Mano, R.A.; Oliveira, D.H.; Maia, D.S.V.; Silva, W.P.; Savegnago, L.; Lenardão, E.J.; Jacob, R.G. Synthesis, Antimicrobial, and Antioxidant Activities of Chalcogen-Containing Nitrone Derivatives from (R)-citronellal. Medicines 2017, 4, 39. [CrossRef] [PubMed]

69. Quintans-Júnior, L.; da Rocha, R.F.; Caregnato, F.F.; Moreira, J.C.; da Silva, F.A.; Araújo, A.A.; dos Santos, J.P.; Melo, M.S.; de Sousa, D.P.; Bonjardim, L.R.; et al. Antinociceptive action and redox properties of citronellal, an essential oil present in lemongrass. J. Med. Food 2011, 14, 630-639. [CrossRef] [PubMed]

70. Saibabu, V.; Singh, S.; Ansari, M.A.; Fatima, Z.; Hameed, S. Insights into the intracellular mechanisms of citronellal in Candida albicans: Implications for reactive oxygen species-mediated necrosis, mitochondrial dysfunction, and DNA damage. Rev. Soc. Bras. Med. Trop. 2017, 50, 524-529. [CrossRef]

71. Ibrahim, S.M.; El- Denshary, E.S.; Abdallah, D.M. Geraniol, Alone and in Combination with Pioglitazone, Ameliorates FructoseInduced Metabolic Syndrome in Rats via the Modulation of Both Inflammatory and Oxidative Stress Status. PLoS ONE 2015, 10, e0117516. [CrossRef]

72. Gerarduzzi, C.; Di Battista, J.A. Myofibroblast repair mechanisms post-inflammatory response: A fibrotic perspective. Inflamm. Res. 2017, 66, 451-465. [CrossRef]

73. Sousa, A.M.; Liu, T.; Guevara, O.; Stevens, J.; Fanburg, B.L.; Gaestel, M.; Toksoz, D.; Kayyali, U.S. Smooth muscle alpha-actin expression and myofibroblast differentiation by TGF $\beta$ are dependent upon MK2. J. Cell. Biochem. 2007, 100, 1581-1592. [CrossRef] 
74. Suzuki, K.; Kim, J.-D.; Ugai, K.; Matsuda, S.; Mikami, H.; Yoshioka, K.; Ikari, J.; Hatano, M.; Fukamizu, A.; Tatsumi, K.; et al. Transcriptomic changes involved in the dedifferentiation of myofibroblasts derived from the lung of a patient with idiopathic pulmonary fibrosis. Mol. Med. Rep. 2020, 22, 1518-1526. [CrossRef] [PubMed]

75. Koga, M.; Kuramochi, M.; Karim, M.R.; Izawa, T.; Kuwamura, M.; Yamate, J. Immunohistochemical characterization of myofibroblasts appearing in isoproterenol-induced rat myocardial fibrosis. J. Vet. Med. Sci. 2019, 81, 127-133. [CrossRef]

76. Zhang, C.Y.; Duan, J.X.; Yang, H.H.; Sun, C.C.; Zhong, W.J.; Tao, J.H.; Guan, X.X.; Jiang, H.L.; Hammock, B.D.; Hwang, S.H.; et al. COX-2/sEH dual inhibitor PTUPB alleviates bleomycin-induced pulmonary fibrosis in mice via inhibiting senescence. FEBS $J$. 2020, 287, 1666-1680. [CrossRef]

77. Phan, S.H. Genesis of the myofibroblast in lung injury and fibrosis. Proc. Am. Thorac. Soc. 2012, 9, 148-152. [CrossRef] [PubMed]

78. Moore, M.W.; Herzog, E.L. Regulation and Relevance of Myofibroblast Responses in Idiopathic Pulmonary Fibrosis. Curr. Pathobiol. Rep. 2013, 1, 199-208. [CrossRef] [PubMed]

79. Zheng, Q.; Tong, M.; Ou, B.; Liu, C.; Hu, C.; Yang, Y. Isorhamnetin protects against bleomycin-induced pulmonary fibrosis by inhibiting endoplasmic reticulum stress and epithelial-mesenchymal transition. Int. J. Mol. Med. 2019, 43, 117-126. [CrossRef] [PubMed]

80. Vallée, A.; Lecarpentier, Y. TGF- $\beta$ in fibrosis by acting as a conductor for contractile properties of myofibroblasts. Cell Biosci. 2019, 9, 98. [CrossRef] [PubMed]

81. Wang, J.-P.; Yu, H.-H.M.; Chiang, E.-R.; Wang, J.-Y.; Chou, P.-H.; Hung, S.-C. Corticosteroid inhibits differentiation of palmar fibromatosis-derived stem cells (FSCs) through downregulation of transforming growth factor- $\beta 1$ (TGF- $\beta 1$ ). PLoS ONE 2018, 13, e0198326. [CrossRef]

82. Ueshima, E.; Fujimori, M.; Kodama, H.; Felsen, D.; Chen, J.; Durack, J.C.; Solomon, S.B.; Coleman, J.A.; Srimathveeravalli, G. Macrophage-secreted TGF- $\beta_{1}$ contributes to fibroblast activation and ureteral stricture after ablation injury. Am. J. Physiol. Ren. Physiol. 2019, 317, F52-F64. [CrossRef]

83. Rago, F.; Melo, E.M.; Kraemer, L.; Galvão, I.; Cassali, G.D.; Santos, R.A.S.; Russo, R.C.; Teixeira, M.M. Effect of preventive or therapeutic treatment with angiotensin 1-7 in a model of bleomycin-induced lung fibrosis in mice. J. Leukoc. Biol. 2019, 106, 677-686. [CrossRef]

84. Zhou, Y.; He, Z.; Gao, Y.; Zheng, R.; Zhang, X.; Zhao, L.; Tan, M. Induced Pluripotent Stem Cells Inhibit Bleomycin-Induced Pulmonary Fibrosis in Mice through Suppressing TGF- $\beta_{1} /$ Smad-Mediated Epithelial to Mesenchymal Transition. Front. Pharm. 2016, 7, 430. [CrossRef] [PubMed] 